\title{
Phages as Therapeutic Tools to Control Major Foodborne Pathogens: Campylobacter and Salmonella
}

\author{
Carla M. Carvalho ${ }^{*}$, Sílvio B. Santos ${ }^{1^{*}}$, Andrew M. Kropinski², \\ Eugénio C. Ferreira ${ }^{1}$ and Joana Azeredo ${ }^{1}$ \\ ${ }^{1} I B B$ - Institute for Biotechnology and Bioengineering, \\ Centre of Biological Engineering, Universidade do Minho, \\ ${ }^{2}$ Laboratory for Foodborne Zoonoses, Public Health Agency of Canada, \\ ${ }^{1}$ Portugal \\ ${ }^{2}$ Canada
}

\section{Introduction}

Foodborne diseases are a growing public health problem worldwide with Campylobacter and Salmonella being the most common and widely distributed causative agents. These Gramnegative bacteria are common inhabitant of the gut of warm-blooded animals, especially livestock, being transmitted to humans primarily through the consumption of contaminated food of animal origin. Poultry meat and derivatives are regarded as the most common source of human salmonellosis and campylobacteriosis.

In addition to the high prevalence of such pathogens and the consequent health problems caused, control of these pathogens has become increasingly difficult due to the emergence of antibiotic-resistant strains. This emergence is a result of the misuse of antimicrobials in food animals, compromising the action of once effective antibiotics in the treatment of foodborne diseases in humans.

Recent legislation restricting the use of antibiotics as growth promoters in animal production, together with the risk of antibiotic-resistant bacteria entering the human food chain have been the driving force for the development of alternative methods for pathogen control. (Bacterio)phages are naturally occurring predators of bacteria, ubiquitous in the environment, with high host specificity and capacity to evolve to overcome bacterial resistance which makes them an appealing option for the control of pathogens. Several studies have been carried to assess the potential use of phages in the control of Campylobacter and Salmonella in animals and food material in order to prevent transmission of these pathogens to humans. Overall, although eradication of the target bacteria is an extremely unlikely event, the proof of principle, that phages are able to reduce the number of these pathogens has been established. Even so, some considerations should be taken into account for an efficient application of phages.

\footnotetext{
${ }^{*}$ These authors contributed equally to this chapter
} 
This chapter aims at giving an overview of the two major foodborne pathogens (Campylobacter and Salmonella), discussing the problems and concerns related to their prevalence and control, focusing mainly on the potential use of phages as an alternative to other control measures. Consequently, the successes and drawbacks of different studies on the use of phages to control Campylobacter and Salmonella will be explored. Moreover several aspects of phage biocontrol will be addressed. These include considerations on phage characterization, phage dose and route of administration, and ways of overcoming the emergence of phage resistant-bacteria. Finally the requisites for an acceptable phage product and the issues related to its public acceptance will be discussed.

\section{Foodborne diseases}

Foodborne diseases are of major concern worldwide. The Centres for Disease Control and Prevention (CDC) estimates that 76 million cases of foodborne diseases occur every year in the United States causing roughly 5000 deaths (Nyachuba, 2010). In Australia the number of cases (5.4 million) has been estimated to have an associated cost of 1.2 billion dollars per year (OzFoodNet Working Group, 2009). The European Food Safety Authority (EFSA) reported a total of 5,550 foodborne outbreaks, causing 48,964 human cases, 4,356 hospitalizations and 46 deaths in 2009 (European Food Safety Authority, 2011). While significant attention is usually given to major foodborne outbreaks, studies indicate that outbreaks only account for a small fraction of Campylobacter and Salmonella infections in humans (European Food Safety Authority, 2009). While a steady decline in the number of cases attributed to Salmonella has been observed since 2004, the number of Campylobacter infections has remained constant (Figure 1). Campylobacteriosis caused 198,252 confirmed human cases in 2009 with a fatality rate of $0.02 \%$, continuing to be the most commonly reported zoonosis in the European Union. A total of 108,614 confirmed human cases were attributed to Salmonella with a fatality rate of $0.08 \%$ in the same year. Moreover there is a considerable underreporting, and the true number of cases of illness caused by these two pathogens is likely to be 10-100 times higher than the reported number (European Food Safety Authority, 2011).

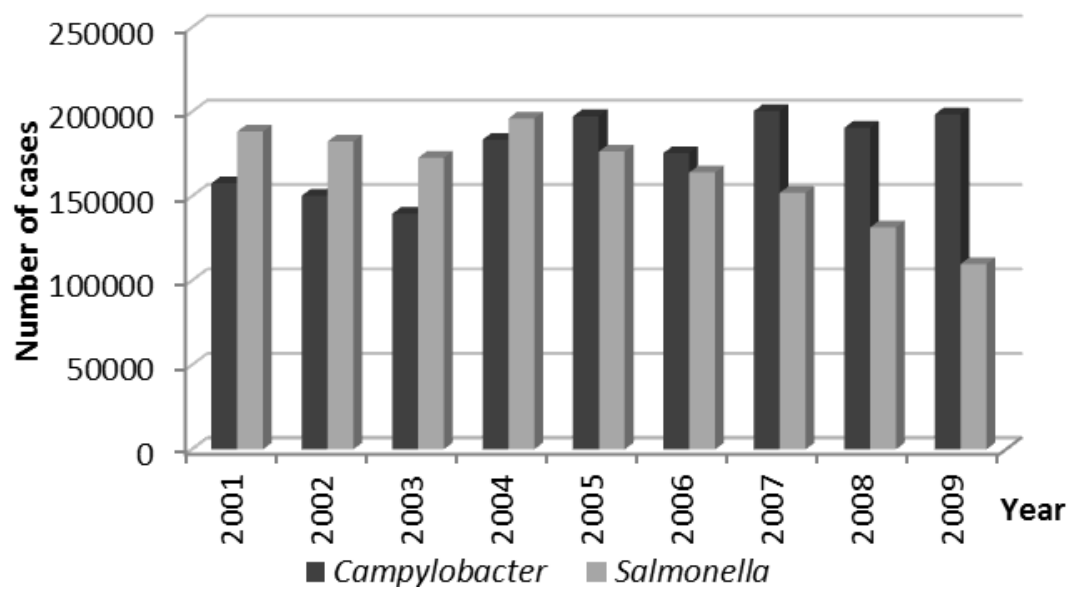

Fig. 1. Number of reported campylobacteriosis and salmonellosis cases in humans 2001-2009 (European Food Safety Authority, 2006; European Food Safety Authority, 2011) 


\subsection{The pathogens}

\subsubsection{Campylobacter}

Campylobacter was first described in 1880 by Theodore Escherich and belongs to the Epsilonproteobacteria, in the order Campylobacterales which includes Helicobacter and Wolinella (Friedman et al., 2000; Keener et al., 2004). The name Campylobacter is derived from the Greek "kampulos" = curved and "bacter" = rod. In fact, bacteria belonging to the genus Campylobacter are non-spore forming, oxidase-positive, Gram-negative, curved or spiral (occasionally straight) rods with $0.2 \mu \mathrm{m}$ to $0.8 \mu \mathrm{m}$ wide and $0.5 \mu \mathrm{m}$ to $5 \mu \mathrm{m}$ long. When they form short or long chains they can appear as S-shaped, V-shaped or more rarely comma shaped. Campylobacter ssp. usually displays a long unsheathed polar flagellum at one (polar) or both (bipolar) ends of the cell which confer to this microorganism a rapid, darting and reciprocating motility (Keener et al., 2004). Campylobacter spp. cells tend to form coccoid and elongated forms on prolonged culture or upon exposure to oxygen (Moran \& Upton, 1987). These cells may be associated to a viable but not culturable state (VBNC). However the association between cell culturability and cell morphology remains controversy (Keener et al., 2004).

The genus Campylobacter now comprises 17 member species. The most commonly isolated are C. jejuni ssp. jejuni, C. coli and C. lari which are referred as thermophilic species. They can grow at $37^{\circ} \mathrm{C}$ to $42^{\circ} \mathrm{C}$ with a $\mathrm{pH}$ in the range of 4.9 to 9.0 , but their optimum growth conditions include a temperature of $42^{\circ} \mathrm{C}$ and a $\mathrm{pH}$ of 6.5 to 7.5 . It is known that they cannot multiply below $30^{\circ} \mathrm{C}$ and that they require a microaerobic atmosphere (approximately $5 \%$ oxygen and 10\% carbon dioxide) (Butzler, 2004).

Contrary to most bacteria, Campylobacter species do not obtain their energy from the metabolism of carbohydrates but instead from amino acids or tricarboxylic acid cycles intermediates. C. jejuni hydrolyzes hippurate and indoxyl metabolizes acetate and reduces nitrate (Butzler, 2004).

\subsubsection{Salmonella}

Investigations on the etiologic agent of the "swine plague" led Theobald Smith, in 1885, to the isolation of a Gram-negative bacillus named Bacterium suipestifer. The bacterium was further characterized by D. E. Salmon from whom the name Salmonella is derived. The nonspore forming cells possess a straight rod-shaped morphology with sizes varying from 0.7 $\mu \mathrm{m}$ to $1.5 \mu \mathrm{m}$ in diameter and $2 \mu \mathrm{m}$ to $5 \mu \mathrm{m}$ in length. These cells are usually motile presenting peritrichous flagella. Salmonella spp. belong to the Enterobacteriaceae family and are chemoorganotrophs (organisms which use organic compounds as their energy source), facultative anaerobes and hydrogen sulphide producers (Bell \& Kyriakides, 2002).

The outer membrane $(\mathrm{OM})$ of Salmonella, as with almost all Gram-negative bacteria, is composed of OM proteins (OMPs) and lipopolysaccharides (LPS). LPS plays an essential role in maintaining the cell structural integrity and protection from chemicals. In the host organisms they act as endotoxins and as a pyrogen displaying a strong immune response. Structurally they are composed by three distinct components: lipid A, core oligosaccharide and O-polysaccharide (Raetz \& Whitfield, 2002). The O-polysaccharide (also O-antigen or Oside-chain) together with the $\mathrm{H}$-antigen (from flagella) and Vi (capsular antigens) are the basis for the Kauffman-White classification scheme, enabling the different Salmonella to be 
grouped in serotypes according to their agglutination pattern when reacted with specific commercial antisera (Bell \& Kyriakides, 2002; Brenner et al., 2000). This classification led to the recognition of more than 2500 serotypes (Bell \& Kyriakides, 2002), a number that increases every year. A revision of the nomenclature has established two species (S. enterica and $S$. bongori) with the majority of the serotypes grouped into one of the six Salmonella subspecies of S. enterica (Bell \& Kyriakides, 2002; Brenner et al., 2000; Velge et al., 2005).

\subsection{The diseases}

Campylobacter and Salmonella are common inhabitant of the gut of warm-blooded animals mainly livestock (such as cattle, sheep, pigs and chickens), domestic pets and wild animals, where they asymptomatically colonize and multiply (Antunes et al., 2003; Bell \& Kyriakides, 2002; Bryan \& Doyle, 1995; Doyle \& Erickson, 2006; Newell \& Fearnley, 2003). As zoonotic agents, Campylobacter and Salmonella can be transferred between humans and other animals. The common route of these pathogens is the consumption of contaminated food of animal origin, particularly meat from pigs, cattle and poultry (and derivatives) and milk. Poultry and derivatives are repeatedly pointed out as the most common sources of infection since the pathogens are present at a high level in fresh poultry meat. Campylobacter and Salmonella strains may also reach humans via routes other than food, directly by the contact with contaminated animals, carcasses or the environment, for example, through drinking water (European Food Safety Authority \& European Centre for Disease Prevention and Control, 2011). Therefore, horizontal transmission appears to have a major role in the transmission of these foodborne pathogens. In contrast to Salmonella, vertical transmission of Campylobacter is generally considered a relatively unimportant route of flock colonization with the consequent general absence of Campylobacter in eggs, one of the most common routes of contamination by Salmonella (European Food Safety Authority, 2011; Newell \& Fearnley, 2003).

These microorganisms have the ability to survive for considerable periods, especially in conditions that are moist, cool and out of direct sunlight. As a result, they can readily contaminate other hosts, as for example, humans where Campylobacter infection is usually associated with illness and for which doses as low as 500 organisms have been reported to cause gastrointestinal disorders (Friedman et al., 2000; Newell \& Fearnley, 2003; Robinson, 1981). As a consequence, bird-to-bird transmission within flocks is very rapid and it was demonstrated that once a broiler flock becomes infected with Campylobacter, close to $100 \%$ of birds are reported to become colonized in a very short time (Allen et al., 2007; Newell \& Fearnley, 2003). Moreover it is known that, after in vivo-passage, organisms can exhibit an enhancement of colonization potential of at least 1,000-fold in most strains and up to 10,000fold in some strains (Berndtson et al., 1992; Keener et al., 2004). The most important Campylobacter species associated with human infections are C. jejuni, C. coli, C. lari and C. upsaliensis (European Food Safety Authority, 2011; Friedman et al., 2000; Robinson, 1981). Campylobacter has become the most recognized antecedent cause of Guillain-Barré syndrome (GBS), an acute post-infectious immune-mediated disorder affecting the peripheral nervous system that can be permanent, fatal or last several weeks and usually requires intensive care (Butzler, 2004; Nachamkin, 2002).

The factors contributing for the high prevalence of these pathogens in poultry meat are bad slaughter conditions, cross-contamination, inadequate heat treatment, raw meat and 
inappropriate food storage (European Food Safety Authority, 2011; Gorman et al., 2002; Hansson et al., 2005; Jacobs-Reitsma, 2000; Johannessen et al., 2007; Luber et al., 2006; van de Giessen et al., 2006). A European Union-wide baseline survey on Campylobacter demonstrated that in EU 71.2\% of broilers are colonized by Campylobacter at the slaughterhouse (European Food Safety Authority, 2010). Therefore, controlling Campylobacter and Salmonella infections has become an important goal particularly for the poultry industry.

Human infection by these pathogens results in a gastrointestinal infection, which is usually characterized by an inflammatory reaction, watery (sometimes bloody) diarrhoea, fever, vomiting, abdominal cramps and dehydration which can become severe and life-threatening as a result of tissue invasion and toxin production (Bell \& Kyriakides, 2002; Butzler, 2004; Friedman et al., 2000; Nachamkin, 2002; Uzzau et al., 2000). Salmonella infections are influenced by the bacterium's host range or degree of host adaptation, enabling the division of the bacteria in two groups: host adapted and ubiquitous. The higher the adaptation of Salmonella to a host, the higher the pathogenicity, with a consequent severity of the disease, usually leading to septicaemia (Bell \& Kyriakides, 2002; Uzzau et al., 2000; Velge et al., 2005). The most prevalent and important Salmonella enterica serotypes reported worldwide are Enteritidis and Typhimurium. These are responsible for $99 \%$ of salmonellosis in humans and warm-blooded animals (Bell \& Kyriakides, 2002; Brenner et al., 2000).

\subsection{Antibiotic resistance}

Antibiotics were introduced in the 1940s and have been widely used in the United States (US) and Europe (EU) in livestock and poultry since the 1950s. In the US at least 17 antimicrobials were approved to be used in food animals. In Europe, all classes of antibiotics licensed for human medicine were allowed for use in animals. As a consequence, antibiotics were used in food animals therapeutically, prophylactically and as food supplements to promote faster growth by improving feed efficiency. The discovery of antibiotics growthenhancing effect became an important element of intense animal husbandry leading to their increased use, often in sub-therapeutic doses in healthy animals and without veterinary prescription (Castanon, 2007; Mathew et al., 2007; Sapkota et al., 2007; World Health Organization, 2002).

The amount of antibiotics used in the absence of disease for non-therapeutic purposes in livestock far exceeds the amount of antimicrobials used in human medicine. It was estimated that 60 to $80 \%$ of the antibiotics produced in the US is used for this purpose. The use of antibiotics in livestock has become a major source of concern because of the possibility that they contribute to the declining efficacy of antibiotics used to treat bacterial infections in humans (Smith et al., 2002). This may happen because antimicrobial agents used for food-producing animals are frequently the same or belong to the same classes as those used in human medicine. The later includes tetracyclines, macrolides and fluoroquinolones (Aarestrup et al., 2008; Mellon et al., 2001; Sapkota et al., 2007).

Two EU agencies, the European Food Safety Authority (EFSA) and the European Centre for Disease Prevention and Control (ECDC), reported recently on the high incidence of antibiotic resistance in Salmonella and Campylobacter, and stated their concern. In fact, the high percentage of Salmonella and Campylobacter isolates displaying resistance to ciprofloxacin is alarming since it represents one of the drugs of choice in human treatment. 
High resistance of Salmonella to tetracyclines, ampicillin and sulphonamides was also reported, as was Campylobacter resistance to high levels of tetracyclines. The EFSA report concluded that the animal antimicrobial usage might be an important factor accounting for the high proportion of resistant isolates (European Food Safety Authority, 2011; European Food Safety Authority \& European Centre for Disease Prevention and Control, 2011; Gyles, 2008; Rabsch et al., 2001).

The resistance problem has led the World Health Organization (WHO) in 2002 to advise and encourage all countries to reduce the use of antibiotics outside human medicine and has already established some measures in the surveillance of foodborne diseases in order to reduce the emergence of resistant bacteria with special concern for Salmonella and Campylobacter (Smith et al., 2005; World Health Organization, 2002). This concern was already present in the EU where several countries have banned the use of antimicrobials that are used in human medicine as growth promoters. The consequent reduction of the selective pressure, has already resulted in a reduction of antimicrobial resistance in a national population of food animals (Aarestrup et al., 2001; Castanon, 2007; Emborg et al., 2003; Smith et al., 2005; Swann, 1969; Tacconelli et al., 2008; Wierup, 2001; World Health Organization, 2002).

Antibiotics are usually the last resource in pathogens control leaving no hope in the treatment of multiresistant bacteria for which no effective antimicrobial exists. Consequently, it can be concluded that an efficient alternative to antibiotics is critical and urgent. In order to control foodborne pathogens, the poultry industry decontaminates carcasses using both chemical and physical treatments. Chemical treatments include washing of carcasses in electrolyzed or chlorinated water, dipping carcasses in a solution containing acidified sodium chlorite before chilling, immersion in acetic or lactic acid or in sodium triphosphate solutions. Physical treatments include freezing of contaminated carcasses, heat-treatment of fresh broiler carcasses, dipping of fresh carcasses in hot water immediately before chilling, radiation, exposure to dry heat, and ultrasonic energy in combination with heat (Corry \& Atabay, 2001; Keener et al., 2004). In spite of the effort that has been done to control these pathogens, they are still a major cause of foodborne diseases (European Food Safety Authority, 2011; Nyachuba, 2010)(Figure 1).

Other possible control measures to eliminate or reduce the contamination of birds are still being developed and their cost-effectiveness and applicability to large-scale production remain to be determined. It includes: vaccination, the use of competitive exclusion, improving genetic resistance of birds and the use of probiotics, bacteriocins and bacteriophages (Chen \& Stern, 2001; García et al., 2008; Joerger, 2001).

\section{Bacteriophages: Novel therapeutic agents}

(Bacterio)phages are viruses that are able to infect Bacteria. Phages are able to infect more than 150 bacterial genera, including aerobes and anaerobes, exospore and endospore formers, cyanobacteria, spirochetes, mycoplasmas, and chlamydias (Ackermann, 2001; Ackermann, 2009).

Structurally they consist of a nucleic acid genome enclosed within a protein or lipoprotein coat and like all viruses are absolute parasites, inert particles outside their hosts, deprived of their own metabolism. Inside their hosts, phages are able to replicate using the host cell as a 
factory to produce new phages particles identical to its ascendant, leading to cell lysis and consequent death of the host (Guttman et al., 2005). As a result of their bacterial parasitism, phages can be found wherever bacteria exist and have already colonized every conceivable habitat. Phages are an extremely diversified group and it has been estimated that ten phage particles exist for each bacterial cell. This fact accounts for an estimated size of the global phage population to be approximately $10^{31}$ particles making phages the most abundant living entities on earth (Rohwer, 2003).

Their presence in the biosphere is especially predominant in the oceans presenting an excess of $10^{7}$ to $10^{8}$ phage particles per millilitre in coastal sea and in non-polluted water and comparably high numbers in other sources like sewage and faeces, soil, sediments, deep thermal vents and in natural bodies of water (Rohwer, 2003). In the absence of available hosts to infect, and as long as they are not damaged by external agents, phages can usually maintain their infective ability for decades (Guttman et al., 2005; Sharp et al., 1986).

\subsection{Phage therapy versus chemotherapy}

Phage therapy presents many potential advantages over the use of antibiotics which are intrinsic to the nature of phages. Phages are highly specific and very effective in lysing the target pathogen, preventing dysbiosis, that is, without disturbing the normal flora and thus reducing the likelihood of super-infection and other complications of normal-flora reduction that can often result following treatment with chemical antibacterials. This high specificity means that diagnosis of the bacteria involved in the infection is required before therapy is employed (Guttman et al., 2005; Marks \& Sharp, 2000; Matsuzaki et al., 2009). The specificity of phages also enables their use in the control of pathogenic bacteria in foods since they will not harm useful bacteria, like starter cultures. Moreover, phages do not affect eukaryotic cells, or cause adverse side effects as revealed through their extensive clinical use in the former Soviet Union. Furthermore, phages are equally effective against multidrug-resistant pathogenic bacteria.

It was also found that phages can rapidly distribute throughout the body reaching most organs including the prostate gland, bones and brain, that are usually not readily accessible to drugs and then multiply in the presence of their hosts (Dabrowska et al., 2005). The selfreplicating nature of phages reduces the need for multiple doses to treat infection diseases since they will replicate in their pathogenic host increasing their concentration over the course of treatment leading to a higher efficacy. This also implies that phages will be present and persist at a higher concentration where their hosts are present, which is where they are more needed, in the place of infection. Reciprocally, where and if the target organism is not present the phages will not replicate and will be removed from the system showing the other side of the self-replicating nature of phages, their self-limiting feature (Goodridge \& Abedon, 2003; Petty et al., 2007).

As it happens with antibiotics, bacteria also develop resistance to phages. The latter usually occurs through loss or modification of cell surface molecules (capsules, OMPs, LPS, pili, flagella) that the phage uses as receptors. Since some of these also function as virulence determinants their loss may in consequence dramatically decrease the virulence of the bacterium or reduce its competitiveness (Levin \& Bull, 2004). A good example is that of Smith (1987) that used phages against the K1 capsule antigen of Escherichia coli and verified 
that resistant K1 bacteria were far less virulent (Smith et al., 1987b). Furthermore, different phages binding to the same bacteria may recognize different receptors and resistance to a specific phage does not result in resistance to all phages. Phages are able to rapidly change in response to the appearance of phage-resistant mutants making them efficient in combating the emergence of newly arising bacterial threats (Matsuzaki et al., 2009; Sulakvelidze et al., 2001). In addition, the isolation of a new phage able to infect the resistant bacteria can be easily accomplished. It is much cheaper, faster and easier to develop a new phage system than a new antibiotic which is a long and expensive process (Petty et al., 2007).

\section{Phage potential in food safety}

Phages can be used to combat pathogens in food at all stages of production in the classic 'farm-to-fork' continuum in the human food chain (García et al., 2008). Accordingly, in order to prevent transmission to humans, phages can be used:

i. in livestock to prevent diseases or reduce colonization;

ii. in food material (such as carcasses and other raw products) or in equipment and contact surfaces to reduce bacterial loads;

iii. in foods as natural preservatives to extend their shelf life.

Several studies have been carried to assess the potential use of phages in the control of Campylobacter and Salmonella in animals and foodstuff. Although very different results have been obtained it seems that the proof of principle has been established: phage therapy has potential in the control of foodborne pathogens (Johnson et al., 2008). The large scale, high throughput and mechanization of poultry production and industry, made poultry and products the most commonly used models for phage biocontrol (Atterbury, 2009). This is reflected in the studies that will be addressed below.

\subsection{Campylobacter and Salmonella phages}

\subsubsection{Campylobacter}

There are relatively few reports on Campylobacter phages probably due to the fastidious growth conditions of their host and to unique features that their phages exhibit. This has hindered the use of conventional methods of phage isolation, propagation and characterization (Bigwood \& Hudson, 2009; Tsuei et al., 2007). Recently Carvalho et al. (2010) described an improved method for Campylobacter phage isolation in which a pre-enrichment of the phages with potential host strains supplemented with divalent cations was used to promote phage adherence to the host (Carvalho et al., 2010b). Campylobacter-specific phages have been isolated from excreta of both broiler and layer chickens, retail poultry, and other sources including pig, cattle and sheep manure, abattoir effluents, and sewage (Connerton et al., 2011). Some of these phages have been characterized and form the basis of the United Kingdom phage typing scheme (Frost et al., 1999; Sails et al., 1998).

The most frequently encountered Campylobacter phages belong to Caudovirales order, Myoviridae family with a double-stranded DNA genome enclosed in icosahedral heads (Connerton et al., 2008). Campylobacter phages have been characterized into three groups according to their genome size and head diameter (Sails et al., 1998): Group I - head diameters of $140 \mathrm{~nm}-143 \mathrm{~nm}$ and large genome sizes of $320 \mathrm{~kb}$; Group II - average head 
diameters of $99 \mathrm{~nm}$ and average genome sizes of $184 \mathrm{~kb}$; Group III - average head diameters of $100 \mathrm{~nm}$ and average genome sizes of $138 \mathrm{~kb}$. Hansen et al. (2007) characterized Campylobacter phages according to their genome size and susceptibility of digestion by HhaI (Hansen et al., 2007).

The DNA of most Campylobacter phages is difficult to extract, clone and sequence and is refractory to restriction enzyme digestion, which is probably due to tightly adherent and proteinase K resistant proteins (Carvalho et al., 2011; Hammerl et al., 2011; Kropinski et al., 2011; Timms et al., 2010). As a consequence, the genome sequence of only five Campylobacter phages have been reported so far (Carvalho et al., 2011; Hammerl et al., 2011; Kropinski et al., 2011; Timms et al., 2010). Interestingly, the phage genomes known are all related and also part of the T4 superfamily of phages (Petrov et al., 2010).

There is little information available regarding the prevalence and influence of phages on Campylobacter-colonized poultry flocks. In fact, the prevalence of Campylobacter phages in poultry has essentially only been described in the UK. It was reported that $C$. jejuni phages were isolated from $20 \%$ of the caeca of chickens sampled in which there was a correlation between the presence of natural environmental phages and a reduction in the numbers of colonizing Campylobacter. Interestingly, birds that harbored phages had a significant difference $(\mathrm{P}<0.001)$ in Campylobacter colony forming units (CFU) per gram in relation to those that did not have phages (Atterbury et al., 2005). Campylobacter phages were prevalent in the caecal contents of organic birds with $51 \%$ of Campylobacter-positive sampled birds also carrying phages. The higher value of phage positive samples in organic flocks can be explained by the fact that these birds are more exposed to the environment and therefore to a greater range of Campylobacter types and phages (El-Shibiny et al., 2005).

It was also showed that, like Campylobacter, their phages are also transferred between flocks (Connerton et al., 2004). Moreover, phages were also recovered from chilled retail poultry, meaning that these phages can survive on retail chicken under commercial storage condition (Atterbury et al., 2003b).

\subsubsection{Salmonella}

Numerous phages infecting Salmonella have been isolated. The first report of a Salmonella phage dates back to 1918 and was described by Félix d'Hérelle. Since then, Salmonella phages have been isolated from different sources: wastewater plants, sewage, manure, faeces and caecal contents from different animals (e.g. poultry, turkey, pig, humans), zoo ponds, nests from poultry farms and many others (Andreatti Filho et al., 2007; Santos et al., 2010; Sillankorva et al., 2010). The search for different Salmonella phages from different sources may be attributed to the interest prompted by the medical and veterinary significance of their pathogenic host.

The great number and different specificity of Salmonella phages has enabled Salmonella classification through phage typing, a useful typing tool for subcategorizing the more common Salmonella enterica serotypes (i.e. S. Typhimurium, S. Enteritidis, S. Heidelberg) recommended by the $\mathrm{WHO}$.

Probably the best known Salmonella phages are the lytic phage Felix 01 and the temperate virus P22. Felix 01 is characterized by its broad lytic spectrum among Salmonella and has 
been used as a diagnostic tool in the identification of Salmonella. Recently, a phage with a broader host range than Felix 01 has been described which presents great potential not only as a therapeutic agent but also as a diagnostic tool (Santos et al., 2010; Santos et al., 2011; Sillankorva et al., 2010) (Figure 2).

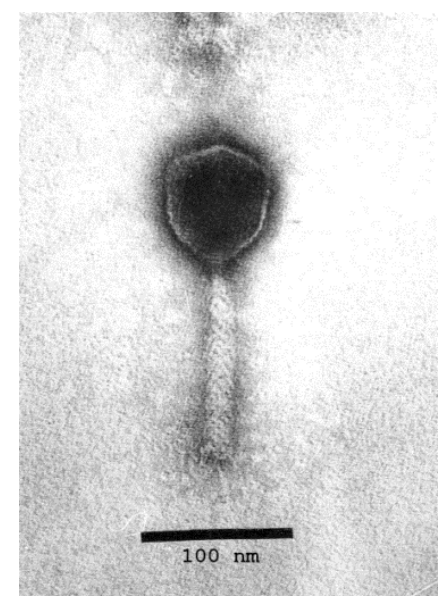

Fig. 2. TEM observation of the broad host range myovirus Salmonella phage PVP-SE1 (Santos et al., 2010)

A survey conducted by Ackermann identified 177 Salmonella phages of which $91 \%$ belong to the Caudovirales order. Their distribution by families is roughly equal with $24 \%$ Myoviridae, 31\% Siphoviridae and 33\% Podoviridae. The 9\% left are distributed in the Inoviridae, Leviviridae, Microviridae, and Tectiviridae families (Ackermann, 2007). A phylogenetic analysis relying on a proteomic comparison resulted in the recognition of at least five groups: P27-like, P2-like, lambdoid, P22-like, and T7-like. Nevertheless, three Salmonella phages (epsilon15, KS7, and Felix O1) are outliers since they could not be attributed to any of the previous groups (Kropinski et al., 2007).

\subsection{Phage biocontrol in livestock}

As already outlined above, contamination of meat products with Campylobacter and Salmonella, as well as other foodborne pathogens, often results from cross-contamination between carcasses and feces from infected animals during slaughter and processing and also during transportation, leading to an increase of bacterial loads. Phage biocontrol in livestock presents two major purposes: i) treatment of bacterial pathogens in animals to minimize its impact on animal health and production and, ii) control of foodborne pathogens contamination to humans through foodstuff or other vectors. Therefore, the use of phages to control pathogens in livestock seems to be a feasible and efficient approach.

In this chapter the term phage therapy will refer only to the use of phages to control bacterial infections in living animals, whereas, the term biocontrol will be used where phages control pathogens in animals and foodstuff (independent of infection) (Hagens \& Loessner, 2010). 


\subsubsection{Campylobacter}

There are only a few reports on phage biocontrol against Campylobacter-infected livestock, with all the studies being conducted on poultry. Wagenaar et al. (2005) assessed both preventive and therapeutic phage treatment (Wagenaar et al., 2005). In their study, multiple doses of a group III phage were administered to chicks before or after being orally challenged with a $C$. jejuni strain. In order to access the effect of phage administration on broilers, the Campylobacter colony forming units (CFU) and the phage plaque forming units (PFU) from caecal contents were enumerated throughout the experimental period. These values were obtained from the group receiving phages and from the control group (in which birds did not received phages). In both treatments, birds were orally challenged with a dose of $1 \times 10^{5} \mathrm{CFU}$ C. jejuni ten days after hatching. Preventive treatment consisted in the oral administration of phage 71 ( $4 \times 10^{9}$ to $2 \times 10^{10} \mathrm{PFU}$ ) for ten consecutive days, starting seven days after hatching. The phage treatment did not prevent the colonization of the caecum, but may had delayed it. In fact, initially the numbers of Campylobacter were reduced by 2 $\log _{10} \mathrm{CFU} / \mathrm{g}$ but after one week the numbers leveled out at approximately $1 \log _{10}$ below that of the controls. In the therapeutic treatment the phage was orally administrated five days after birds being challenged with $C$. jejuni and consecutively during the next six days. The numbers of Campylobacter had decreased $3 \log _{10} \mathrm{CFU} / \mathrm{g}$ at $48 \mathrm{~h}$, but after five days stabilized to approximately $1 \log _{10} \mathrm{CFU} / \mathrm{g}$ below the control group. In order to mimic the "farm condition" in which birds are normally slaughter at 42 days, birds were orally challenged with a dose of $1 X 10^{5} \mathrm{CFU} C$. jejuni at 32 days after hatching. Seven days later phages 71 and 69 were orally administered to these birds and for four consecutive days. As occurred with the previously described treated group, the values of Campylobacter counts dropped initially $1.5 \log _{10} \mathrm{CFU} / \mathrm{g}$ but then stabilized at $1 \log _{10}$ unit lower than in the controls.

In the study by Loc Carrillo et al. (2005), broiler chicks at 20 to 22-day-old were challenged with C. jejuni strains isolates HPC5 and GIIC8 from United Kingdom broiler flocks that have proved to be good colonizers (Loc Carrillo et al., 2005). The chicks received four different doses of HPC5 (2.7 $\log _{10}$ CFU, $3.8 \log _{10}$ CFU, $5.8 \log _{10}$ CFU and $7.9 \log _{10}$ CFU) and after $48 \mathrm{~h}$ the Campylobacter numbers in the caeca, upper and lower intestine were enumerated. The highest dose led to more reproducible colonization levels of all intestinal sites examined, with a mean value of $6.3 \log _{10} \mathrm{CFU} / \mathrm{g}, 6.7 \log _{10} \mathrm{CFU} / \mathrm{g}$ and $7.4 \log _{10} \mathrm{CFU} / \mathrm{g}$ in the upper intestine, lower intestine and caeca respectively. Moreover these colonization levels, which are similar to those of naturally colonized birds (Rosenquist et al., 2006), were maintained over nine days. The phage treatment occurred five days after the $C$. jejuni challenge. Birds were treated orally with two phages (CP8 or CP34) independently at a dose of $10^{5}, 10^{7}$ or $10^{9}$ PFU. The phages were administered in an antacid suspension $\left(\mathrm{CaCO}_{3}\right)$ since it proved to protect phages from exposure to low $\mathrm{pH}$ during passage through the gastrointestinal tract. The administration of $10^{7} \mathrm{PFU}$ was the dose which led to the highest reduction $\left(3.9 \log _{10}\right.$ $\mathrm{CFU} / \mathrm{g}$ ) in the upper and lower intestine and caecal counts of Campylobacter at $24 \mathrm{~h}$. The highest dose was less effective in the treatment probably due to the aggregation and nonspecific association of phages with digesta, non-host bacteria or bacterial cell debris resulting from "lysis from without" (Rabinovitch et al., 2003). Different host-phage combinations were tested in vivo, leading to different results. In fact, and contrarily to the results obtained in vitro, phage CP34 was more effective in the reduction of $C$. jejuni HPC5 at all intestinal sites compared to CP8. Conversely phage CP8 was efficient in the reduction of Campylobacter counts by more than $5 \log _{10} \mathrm{CFU} / \mathrm{g}$ in caecal Campylobacter counts. Despite 
this initial reduction, the C. jejuni numbers started to increase $72 \mathrm{~h}$ after phage administration with the lower intestinal counts exhibiting significant differences of $2.1 \log _{10}$ and $1.8 \log _{10} \mathrm{CFU} / \mathrm{g}$ but with the upper intestinal counts showing no significant difference with the Campylobacter levels recorded for the control group.

El-Shibiny et al. (2009) reported the administration of a group II Campylobacter phage (CP220) to C. coli and C. jejuni colonized chickens (El-Shibiny et al., 2009). The results showed that a 2 $\log _{10} \mathrm{CFU} / \mathrm{g}$ reduction in Campylobacter counts was observed when a single $10^{7}$ or $10^{9} \mathrm{PFU}$ dose of CP220 was administered to $C$. jejuni or C. coli colonized chickens, respectively. After this treatment, only $2 \%$ of the recovered Campylobacter displayed resistance to CP220.

Recently, Carvalho et al. (2010) tested a phage cocktail composed by three group II Campylobacter phages (Figure 3) in chicks that were previously challenged with C. coli strain A11 or C. jejuni strain 2140 (Carvalho et al., 2010a). Again, colonization models were established before phage therapy experiments were performed in order to access the effective reduction in Campylobacter numbers. In order to determine the optimum dose of Campylobacter that should be given to birds, the animals were challenged with three different concentrations $\left(10^{4}, 10^{6}\right.$ or $\left.5.5 \times 10^{7} \mathrm{CFU}\right)$ of an overnight culture of $C$. jejuni and sampling points were obtained during seven days. The results obtained revealed that the dose of Campylobacter appeared to have little effect on the outcome of subsequent colonization and that the mean level of colonization was $2.4 \times 10^{6} \mathrm{CFU} / \mathrm{g}$, which is within the range of the infection levels found in commercial broilers (Rosenquist et al., 2006). Seven days post-infection, a single dose of a phage cocktail was administered to chicks by two different routes: oral gavage and incorporated into their feed. Sampling points were taken for seven days after phage administration and showed that the phage cocktail was able to reduce by approximately $2 \log _{10} \mathrm{CFU} / \mathrm{g}$ the titre of both $\mathrm{C}$. coli and C. jejuni in faeces of colonized chickens. This reduction persisted throughout the experimental period and none of the pathogens regained their former numbers. The administration in feed led to an earlier and more sustainable reduction of Campylobacter than administration by oral gavage. The phage titers from faecal samples of the chicks infected with Campylobacter remained approximately constant throughout the experimental period showing that phages delivered to chicks (either by oral gavage or in feed) were able to replicate and therefore able to reduce the Campylobacter populations.
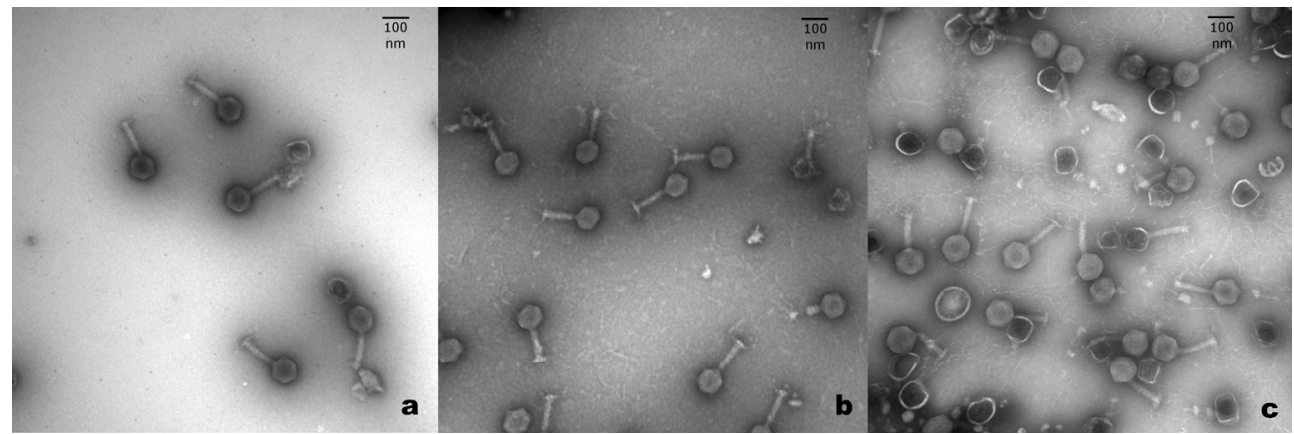

Fig. 3. TEM observation of the three Campylobacter phages, belonging to the family Myoviridae, which make up the cocktail used in the in vivo experiments by Carvalho et al. (2010): a) phiCcoIBB12, b) phiCcoIBB35, c) phiCcoIBB37 (Carvalho et al., 2010a) 
The appearance of phage resistant mutants has always been seen as a major drawback of phage therapy. Nevertheless some of the above mentioned studies found that phage resistance can be associated with a reduced colonization potential in the chicken intestine, suggesting that there is a fitness cost to phage resistance in which phage-resistant Campylobacter revert to a sensitive phenotype when re-colonizing the chicken intestine in the absence of phage predation. It was also suggested that genomic instability of $C$. jejuni in the avian gut can be seen as a mechanism to temporarily survive phage predation and later competition for resources (Carvalho et al., 2010a; Loc Carrillo et al., 2005; Scott et al., 2007a; Scott et al., 2007b). Conversely, recent studies by Carvalho et al. (2010) reported that Campylobacter strains resistant to phage infection were recovered from phage-treated chickens at a frequency of $13 \%$ and that these resistant phenotypes did not exhibit a reduced ability to colonize the chicken guts and did not revert to sensitive types (Carvalho et al., 2010a).

\subsubsection{Salmonella}

The importance and impact of Salmonella has elicited several studies on the use of phages on the control of this pathogen. Although poultry represents the most commonly used models, studies also exist in pigs.

In 1991, Berchieri and colleagues used a chicken model to assess the potential of phages to control Salmonella Typhimurium in chickens. In the established model, oral infection with $10^{9} \mathrm{CFU}$ of Salmonella was fatal in $53 \%$ of the chickens. Oral administration of phage at high concentration (greater than $1010 \mathrm{PFU} / \mathrm{ml}$ ), soon after Salmonella infection, was able to significantly reduce mortality (from $60 \%$ to $3 \%$ ) as well as the number of pathogens in the alimentary tract. The high dose required for the reduction of Salmonella suggests that control by the phage was made by "lysis from without" or by a single cycle of replication. Although pathogen numbers were reduced shortly after phage administration, they increased soon after. Moreover, the phage was only present in the intestine when Salmonella was found in numbers above $10^{6} \mathrm{CFU} / \mathrm{ml}$ (Berchieri et al., 1991). Therefore, an efficient application of the phage required that administration should be right after infection and even so bacterial control was possible only for a short period. This may be attributed to the ability of Salmonella to internalize cells thus escaping from phages. As with the Campylobacter studies (see above) phage resistant bacteria were also found to present rough morphology and to display less virulence than the wild strain. More than one phage was used in this study and one of these, although lytic in vitro, was not effective in vivo showing the importance of in vivo trials.

Fiorentin et al. (2005) used a cocktail of three phages to control S. Enteritidis PT4 in broilers. The phage dose administered was also very high (1011 PFUs of each phage). In this study phage was administered only seven days post infection and a $3.5 \log _{10}$ CFU reduction per gram of caecal content was recorded five days later. This level remained for 25 days. It seems here that time of administration was not critical but phage dose was. Although a high dose and a cocktail of phages were used with the purpose of reducing the possibility of phage resistant bacteria emergence, the presence of such cells was not assessed (Fiorentin et al., 2005).

When a similar dose (1011 PFUs) was given orally two days after infection, Atterbury et al. (2007) were able to achieve a reduction of the caecal colonization of both $S$. Enteritidis and $S$. 
Typhimurium in broiler chickens by up to $4.2 \log _{10} \mathrm{CFU} / \mathrm{g}$. Lower doses were ineffective in achieving similar results. A third phage tested in this study against $S$. Hadar did not reduce bacterial counts despite its strong lytic activity in vitro against that strain. The emergence of resistant bacteria was here also a reality with the number of phage resistant Salmonella increasing with the PFUs administered. This subpopulation of resistant bacteria was able to recolonize the broiler chickens within 72 hours after phage treatment. Interestingly, when these resistant bacteria were used to colonize a new group of chickens, they reverted to their phage-sensitive phenotype (Atterbury et al., 2007).

Borie et al. (2008) pretreated ten day old broiler chicks, by coarse spray or drinking water containing a cocktail of three phages 24 hours before administering roughly $10^{6}$ CFUs of Salmonella Enteritidis (calculated multiplicity of infection (MOI) of $10^{3}$ ). After ten days of infection phages were recovered from the intestinal and other organs. A significant reduction in Salmonella Enteritidis was obtained at that time for both routes of administration with a reduction of more than $1 \log _{10} \mathrm{CFU} / \mathrm{ml}$ in challenged bacterial numbers. This study demonstrates not only that phages are able to reduce Salmonella bacterial loads in broiler chickens but also that aerosol spray and drinking water are conceivable routes of administration in the application of a phage product which will surely facilitate application and establishment of phage biocontrol in an industrial environment (Borie et al., 2008). In a later study these authors, using seven days old chicks were able to replicate the aerosol results. Moreover, they showed that phage treatment coupled with competitive exclusion resulted in even better Salmonella reductions than each of the treatments alone (Borie et al., 2009).

Toro et al. (2005) and coworkers also tested the association of phage therapy and competitive exclusion in the treatment of chickens infected experimentally with Salmonella. Phage treatment was given orally and included a cocktail of three different phages with different host ranges. In all treated groups, with phage or competitive exclusion alone or together, a decrease in the Salmonella counts was observed with a reduction to marginal levels in the ileum and a six fold reduction in the caeca in the case of the group treated with the phage cocktail. Moreover, there was a marginally improved weight gain in the treated animals. Although both approaches were able to reduce the Salmonella counts, unlike the previous study (Borie et al., 2009) a synergistic effect was not observed (Toro et al., 2005).

In 2007 Andreatti Filho and colleagues reported on the isolation and testing of two different phage cocktails (one with 4 phages and another with 45 phages) in the control of Salmonella in vivo and in vitro. In vitro test of these two preparations at concentrations of $10^{5}$ to $10^{9}$ $\mathrm{PFU} / \mathrm{ml}$ in simulated crop environment resulted in a 1.5 or $5 \log _{10}$ reduction of Salmonella Enteritidis, respectively for the 4-phage and 45-phage cocktails in two hours after treatment. Although the 4-phage cocktail did not produce a reduction at six hours post-treatment, the 45-phage cocktail was able to reduce bacterial counts by $6 \log _{10}$. This study clearly shows the advantage of a cocktail with a large number of phages, probably enabling complementary host range between phages and broader action in bacteria. Phage cocktails were administered at $10^{8}$ PFU by oral gavage to day-of-hatch chicks infected with $9 \times 10^{3} \mathrm{CFU}$ of Salmonella Enteritidis. These showed significant reduction of Salmonella recovered from caecal tonsils after 24 hours of treatment but no difference was observed at 48 hours when compared with the control group. Another experiment combined the use of the 45-phage cocktail with a commercial probiotic (and controls with each alone) to treat day-of-hatch 
chicks achieving significant reductions in Salmonella recovery from caecal tonsils at 24 hours but no additive or synergistic effect was observed when combining both approaches. Once again, phage therapy was only efficient during a short period and no long term protection was observed (Andreatti Filho et al., 2007).

Recently, Wall et al. (2010) tested the efficacy of a cocktail to treat S. Typhimurium experimentally infected pigs shortly before processing in order to reduce carcass contamination. Administration of the phage at the time of infection resulted in a $2-3 \log _{10}$ reduction of Salmonella colonization (Wall et al., 2010).

O'Flynn et al., (2006) isolated two broad host range Salmonella phages (st104a and st104b) which were partially resistant to the porcine gastric juice ( $\mathrm{pH} 2.5$ ). In vitro tests showed a reduction of more than $2 \log _{10}$ in Salmonella numbers in just one hour demonstrating their potential in controlling Salmonella in pigs by oral administration. Even so, as seen in other studies, for an efficient assessment of their potential as therapeutic agents, in vivo tests are needed (O'Flynn et al., 2006).

\begin{tabular}{|c|c|c|c|}
\hline $\begin{array}{l}\text { Target } \\
\text { pathogen }\end{array}$ & Livestock & Results & References \\
\hline \multirow{4}{*}{ 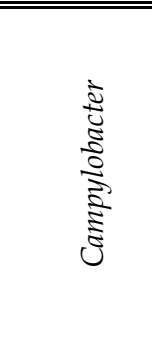 } & chicken & $\begin{array}{l}\text { Reduction of up to } 3 \log _{10} \mathrm{CFU} / \mathrm{g} \text { in caecal } \\
\text { samples }\end{array}$ & $\begin{array}{l}\text { (Wagenaar et al., } \\
\text { 2005) }\end{array}$ \\
\hline & chicken & $\begin{array}{l}\text { Reduction of more than } 5 \log _{10} \mathrm{CFU} \text { in caecal } \\
\text { samples }\end{array}$ & $\begin{array}{l}\text { (Loc Carrillo et } \\
\text { al., 2005) }\end{array}$ \\
\hline & chicken & $\begin{array}{l}\text { Reduction of up to } 2 \log _{10} \mathrm{CFU} / \mathrm{g} \text { in caecal } \\
\text { samples }\end{array}$ & $\begin{array}{l}\text { (El-Shibiny et al., } \\
\text { 2009) }\end{array}$ \\
\hline & chicken & $\begin{array}{l}\text { Reduction of up to } 2 \log _{10} \mathrm{CFU} / \mathrm{g} \text { (faster } \\
\text { reduction when administrated in feed) }\end{array}$ & $\begin{array}{l}\text { (Carvalho et al., } \\
\text { 2010a) }\end{array}$ \\
\hline \multirow{8}{*}{ 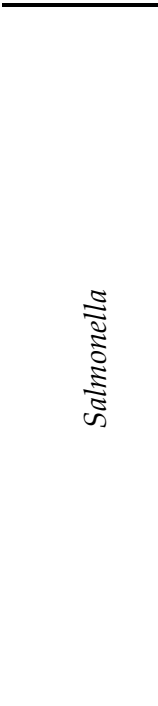 } & chicken & Reduction from $60 \%$ to $3 \%$ in chicken mortality & $\begin{array}{l}\text { (Berchieri et al., } \\
\text { 1991) }\end{array}$ \\
\hline & chicken & $\begin{array}{l}\text { Reduction of up to } 3.5 \log _{10} \mathrm{CFU} / \mathrm{g} \text { of caecal } \\
\text { content }\end{array}$ & $\begin{array}{l}\text { (Fiorentin et al., } \\
\text { 2005) }\end{array}$ \\
\hline & chicken & $\begin{array}{l}\text { Reduction of up to } 4.2 \log _{10} \mathrm{CFU} \text { of the caecal } \\
\text { colonization }\end{array}$ & $\begin{array}{l}\text { (Atterbury et al., } \\
\text { 2007) }\end{array}$ \\
\hline & chicken & $\begin{array}{l}\text { Reduction of up to } 1.63 \log _{10} \mathrm{CFU} / \mathrm{ml} \text { in } \\
\text { Salmonella recovery from the intestine. }\end{array}$ & $\begin{array}{l}\text { (Borie et al., 2008; } \\
\text { Borie et al., 2009) }\end{array}$ \\
\hline & chicken & $\begin{array}{l}\text { Reduction of up to marginal levels in the ileum } \\
\text { and six fold in the caeca in the Salmonella counts }\end{array}$ & $\begin{array}{l}\text { (Toro et al., } \\
\text { 2005) }\end{array}$ \\
\hline & chicken & $\begin{array}{l}\text { Reduction of up to } 6 \log _{10} \text { in simulated crop } \\
\text { environment / } 55 \% \text { in recovery from caecal } \\
\text { tonsils of chicks }\end{array}$ & $\begin{array}{l}\text { (Andreatti Filho } \\
\text { et al., 2007) }\end{array}$ \\
\hline & pig & $\begin{array}{l}\text { Reduction of up to } 3 \log _{10} \text { reduction of } \\
\text { Salmonella colonization }\end{array}$ & $\begin{array}{l}\text { (Wall et al., } \\
\text { 2010) }\end{array}$ \\
\hline & pig & $\begin{array}{l}\text { Reduction of up to } 2 \log _{10} \text { in Salmonella numbers } \\
\text { (in vitro test) }\end{array}$ & $\begin{array}{l}\text { (O'Flynn et al., } \\
\text { 2006) }\end{array}$ \\
\hline
\end{tabular}

Table 1. Studies on phage biocontrol in livestock 


\subsection{Phage biocontrol in food material}

Another way that phages may be used to improve food safety is to apply them directly onto raw food products. The practical applicability of this approach may be compromised by the minimum density of host cells that are suggested to be required for phage replication (Payne et al., 2000; Payne \& Jansen, 2001). Nevertheless it was demonstrated that phages can be effective biocontrol agents when the population of host cells is as low as $46 \mathrm{CFU} / \mathrm{cm}^{2}$ (Greer, 1988). These contradictory results may be a consequence of differences in phage/host combinations, in the matrix used, in the presence of non-host decoys or even in the models applied. Therefore, the efficacy of phage-based biocontrol should be determined on a caseby-case basis (Atterbury, 2009).

The application of phages as biocontrol agents has been investigated in a variety of food matrices. Nevertheless most studies focus in poultry products, with Campylobacter and Salmonella being the most frequently targeted zoonotic pathogens.

\subsubsection{Campylobacter}

Most studies on the use of phages as biocontrol are devoted to pre-harvesting studies. In fact, there are only few studies reporting the efficacy of Campylobacter phages in foodstuff.

Atterbury et al. (2003) studied the survival of C. jejuni and phages on chicken skin at temperatures of $4^{\circ} \mathrm{C}$ or $-20^{\circ} \mathrm{C}$. A dose of $10^{6} \mathrm{CFU}$ C. jejuni NCTC 12662 PT14 was inoculated on the surface of chicken skin and then samples were stored at these two temperatures for a period of one hour to ten days (Atterbury et al., 2003a). The results showed that there was a reduction of 1 or $2 \log _{10} \mathrm{CFU}$ on Campylobacter counts for skin stored at $4^{\circ} \mathrm{C}$ or $-20^{\circ} \mathrm{C}$, respectively. This reduction was lower than the value normally reported for Campylobacter cells stored at $-20^{\circ} \mathrm{C}\left(3 \log _{10} \mathrm{CFU}\right)$ (Chan et al., 2001), which indicates that chicken skin may have had a protective effect. Phage $\varphi 2$ at $10^{7} \mathrm{PFU}$ was added to chicken skin samples and was show to survive for ten days at $4^{\circ} \mathrm{C}$ and at $-20^{\circ} \mathrm{C}$. In order to access whether this phage would attach non-specifically to non-susceptible Campylobacter strains at $4^{\circ} \mathrm{C}$, this phage was added to C. coli NCTC 12667 at a MOI of 10 for ten days. In fact, Campylobacter counts and phage titer did not fall during the experimental period which indicates that a nonspecific adsorption did not occur. Conversely when the same phage was added to its susceptible host, under the same conditions described above, the Campylobacter numbers were reduced by $0.8 \log _{10} \mathrm{CFU} / \mathrm{ml}$ (Atterbury et al., 2003a).

In another experiment performed by the same authors, phage $\varphi 2$ and C. jejuni NCTC 12662 PT14 were added to chicken skin samples at different MOI ranging from $10^{-3}$ to $10^{5}$ with samples stored at $4^{\circ} \mathrm{C}$ and $-20^{\circ} \mathrm{C}$ for five days. The results again showed a significant reduction in Campylobacter counts when the virus were administered at the highest MOI: a $1.1 \log _{10}$ to $1.3 \log _{10}$ CFU reduction in samples stored at $4^{\circ} \mathrm{C}$ and a $2.3 \log _{10}$ to $2.5 \log _{10} \mathrm{CFU}$ reduction for frozen samples. Overall, the treatment that showed the best reduction in Campylobacter counts in chicken skin was the one in which high phage titers were applied following by storage of samples at freezing temperatures. Nevertheless, in all the treatments phages were not able to replicate. Furthermore, Campylobacter strains recovered after phage treatments were shown to be identical to the inoculated strains and did not display resistance to this phage (Atterbury et al., 2003a). 
Goode et al. (2003) also demonstrated the reduction in Campylobacter levels, after the application of a lytic phage to chicken skin, experimentally contaminated with C. jejuni. Chicken portions were initially inoculated with $10^{4} \mathrm{CFU} / \mathrm{cm}^{2}$ of C. jejuni strain C222 and then half of the chicken pieces were treated with $C$. jejuni typing phage 12673 at an approximate density of $10^{6} \mathrm{PFU} / \mathrm{cm}^{2}$. The samples were incubated at $4^{\circ} \mathrm{C}$ and swabs were taken after $24 \mathrm{~h}$. The results obtained show that Campylobacter counts were reduced by 1.3 $\log _{10}$ CFU comparing with the control. However, there was even a reduction of approximately $1 \log _{10} \mathrm{CFU}$ in the Campylobacter numbers from the non-phage-treated chicken portions, which meant that Campylobacter did not survive well on exposed chicken surfaces at $4^{\circ} \mathrm{C}$ (Goode et al., 2003).

In 2008 Bigwood et al. (2008) reported on an investigation into the use of phage Cj6 against C. jejuni inoculated on cooked and raw meat and incubated for $24 \mathrm{~h}$ at two different temperatures $\left(5^{\circ} \mathrm{C}\right.$ and $\left.24^{\circ} \mathrm{C}\right)$ in order to simulate refrigerated and room temperature storage. Experiments were performed using different conditions: low $\left(<100 \mathrm{cells} / \mathrm{cm}^{2}\right)$ or high $\left(10^{4}\right.$ cells $\left./ \mathrm{cm}^{2}\right)$ host densities and low (10) or high $\left(10^{4}\right)$ MOIs. When the experimental conditions were set for $5^{\circ} \mathrm{C}$, significant differences were obtained for samples inoculated with high MOI and high host density. A reduction of $2.4 \log _{10} \mathrm{CFU} / \mathrm{cm}^{2}$ and $1.5 \log _{10}$ $\mathrm{CFU} / \mathrm{cm}^{2}$ was obtained on cooked and raw meat, respectively. The titer of phages inoculated was also reduced by $10 \%$, after $24 \mathrm{~h}$ of incubation on cooked meat. When samples were stored at $24^{\circ} \mathrm{C}$, at high MOI and low host density, the reduction in Campylobacter counts was not significant. However when samples were inoculated at high MOI and high host density, reduction of $2.8 \log _{10} \mathrm{CFU} / \mathrm{cm}^{2}$ (after 6h) and $2.2 \log _{10} \mathrm{CFU} / \mathrm{cm}^{2}$ (after $24 \mathrm{~h}$ ) were obtained on cooked and raw meat, respectively. Nevertheless, Campylobacter counts were reduced, even in the untreated samples, which may be explained by their sensitivity to the experimental temperatures. Therefore the results did not allow an accurate assessment of the effective reduction by the phage treatment (Bigwood et al., 2008).

Overall the studies suggest that high MOI values are more effective in the control of Campylobacter in foods. From the studies outlined above it is evident that Campylobacter are not able to grow and multiply under the conditions found on refrigerated raw meat, which renders unlikely phage replication. Nevertheless even if the phage cannot replicate at that temperatures, when reaching the human intestine, bacteria increases its metabolic activity and phages may eventually attach and lyse the target bacteria, leading to a control effect (Goode et al., 2003).

\subsubsection{Salmonella}

Different approaches have been used to assess the effectiveness of phages to control pathogens in foodstuff. Salmonella control in poultry products has been constantly highlighted. Goode et al. (2003) also used phages to treat chicken skin experimentally contaminated with Salmonella Enteritidis $\left(10^{3} \mathrm{CFU} / \mathrm{cm}^{2}\right)$. Different MOIs were tested and for a $\mathrm{MOI}=1$ the phages were able to replicate increasing their number with the consequent reduction of bacteria by less than $1 \log _{10}$ in 24 hours. For higher MOIs $\left(10^{2}\right.$ and $\left.10^{3}\right)$ the levels of recovered Salmonella were reduced by roughly $2 \log _{10}$ over $48 \mathrm{~h}$. Using even a higher MOI $\left(10^{5}\right)$ to treat a more realistic Salmonella contamination level $\left(<10^{2} \mathrm{CFUs}\right)$ no recoverable Salmonella was obtained, resulting in the total elimination of the pathogen (Goode et al., 2003). 
The use of phages to reduce contamination of pig skin was studied by Hooton et al. (2011). In their study on pig skin artificially contaminated with Salmonella Typhimurium U288 (the most prevalent serovar found in pigs) at levels of $10^{3} \mathrm{CFU}$, a cocktail of four phages which included Felix 01 was employed at a temperature of $4^{\circ} \mathrm{C}$. Although the application of the phage cocktail at MOI of 1 or less produce little or no reduction, the use of MOI above 10 led to a reduction of the pathogen below detectable levels (Hooton et al., 2011).

The effectiveness of phages to control Salmonella in carcasses of broiler chickens and turkeys was tested by Higgins et al. (2005). In this study, $10^{6}$ PFU of a phage applied to carcasses was deemed to be inefficient in the removal of $S$. Enteritidis at levels below $10^{3}$. Instead, application of $\geq 10^{8}$ PFU resulted in a marked reduction in the numbers of carcasses with recoverable Salmonella. Higgins et al. also used a cocktail composed of 72 different Salmonella phages to treat naturally contaminated turkey carcasses. The results are promising showing that the cocktail effectively reduced Salmonella recovery from the contaminated carcasses. These studies suggest that a high concentration of phage, preferably a cocktail of different phages, should be used to efficiently treat carcasses contaminated with Salmonella (Higgins et al., 2005).

Control of Salmonella through the action of phages was also tested in raw and cooked beef by Bigwood et al. (2008). The samples were inoculated with Salmonella at low or high densities (respectively $<10^{2}$ or $10^{4} \mathrm{CFU} / \mathrm{cm}^{2}$ ). Afterwards, phages were added at a MOI of $10^{1}$ or $10^{4}$ and samples incubated at different temperatures to simulate refrigerated and room temperature storage (respectively $5^{\circ} \mathrm{C}$ and $24^{\circ} \mathrm{C}$ ). Phages were able to reduce Salmonella counts in up to $2.3 \log _{10} \mathrm{CFU} / \mathrm{cm}^{2}$ for samples incubated at $5^{\circ} \mathrm{C}$ and in more than $5.9 \log _{10} \mathrm{CFU} / \mathrm{cm}^{2}$ for samples incubated at $24^{\circ} \mathrm{C}$ when compared to controls (samples inoculated with Salmonella without phage). These results were obtained for both high densities of Salmonella $\left(10^{4} \mathrm{CFU} / \mathrm{cm}^{2}\right)$ and phages applied at a high MOI $\left(10^{4}\right)$ with samples incubated for $24 \mathrm{~h}$. The reductions were even higher after eight days of incubation. For low Salmonella densities the reductions were not significant for the majority of the samples. Interestingly, recovered Salmonella cells were found to still be sensitive to phage infection (Bigwood et al., 2008).

The well-known broad host range Salmonella phage Felix 01 was used by Whichard et al. (2003) to treat chicken sausages contaminated with S. Typhimurium DT104 (300 CFU) and a reduction of up to $2.1 \log _{10}$ in the Salmonella levels was obtained (Whichard et al., 2003).

Control of Salmonella in foodstuff has not been restricted only to meat and derivates. A study carried by Leverentz and colleagues examined the efficiency of phage to control Salmonella on fresh-cut fruit, a rapidly developing industry. Treatment with a phage mixture was able to reduce the numbers of Salmonella by nearly $3.5 \log _{10}$ CFU/g in honeydew melon slices stored at $5{ }^{\circ} \mathrm{C}$ and $10^{\circ} \mathrm{C}$, temperatures at which Salmonella can survive or increase up to $2 \log _{10}$ respectively within a week. At $20^{\circ} \mathrm{C}$, where Salmonella loads can increase up to $5 \log _{10}$, the decrease of Salmonella in slices was of $2.5 \log _{10}$. The reductions obtained were greater than the maximal amount achieved using chemical sanitizers. Although this marked reduction in melons, in apple slices this did not happen. The reason may rely in the lower $\mathrm{pH}$ of apples that does not enables phage survival since it was not possible to reisolate phages in the apple 48 hours post treatment while in the melons the phage concentration was stable during this time period (Leverentz et al., 2001a). 
Pao et al. (2004) used phages to treat sprouting seeds where it was found that Salmonella grows during soaking. Treatment with phages could reduce the numbers of Salmonella in $1.37 \log _{10}$ and $1.5 \log _{10}$ in mustard seeds and in the soaking water of broccoli seeds by using one or two phages respectively (Pao et al., 2004).

Cheese contamination by Salmonella was also subject of study on possible biocontrol with phages. Modi et al. (2001) following standard procedures made cheddar cheese from raw and pasteurized milk (an important vehicle of Salmonella transmission to humans) (European Food Safety Authority, 2011). The cheese was inoculated with $10^{4} \mathrm{CFU} / \mathrm{ml}$ of $S$. Enteritidis and $10^{8} \mathrm{PFU} / \mathrm{ml}$ of the Salmonella phage SJ2 (Modi et al., 2001). A decrease in Salmonella counts by 1 to $2 \log _{10}$ was observed in raw and pasteurized milk cheeses while in the controls (cheeses made from milks inoculated with only Salmonella and no phage) an increase of $1 \log _{10}$ was observed. After storage of the cheeses for 99 days at $8^{\circ} \mathrm{C}$ Salmonella was present in the controls at a final concentration of $10^{3} \mathrm{CFU} / \mathrm{g}$. In the phage treated cheeses only $50 \mathrm{CFU} / \mathrm{g}$ were present in the ones from raw milk and no Salmonella was recovered from pasteurized milk cheeses after 89 days.

Composting is a complex process used not only to obtain a nutrient-rich substrate but also to significantly reduce pathogen contamination. Even so, improperly composting may result in Salmonella survival and thus constitute a vehicle of Salmonella transmission to animals and humans. Heringa et al. (2010) used a cocktail of five phages to treat a dairy manure compost inoculated with $S$. Typhimurium and observed a $2 \log _{10}$ reduction within four hours and 3 $\log _{10}$ reduction within 34 hours compared to the controls (Heringa et al., 2010).

Reduction of Salmonella through the action of phages was also investigated in wastewater. Turki et al. (2011) isolated three different phages and tested their ability to reduce Salmonella in TSB medium at two temperatures $\left(30^{\circ} \mathrm{C}\right.$ and $\left.37^{\circ} \mathrm{C}\right)$. Phages were applied at three different MOI $\left(10^{0}, 10^{2}\right.$ and $\left.10^{4}\right)$ alone or as a cocktail of two or three phages. The three phage cocktail was able to reduce all Salmonella cultures at both temperatures when using a high MOI. Although, addition of individual or combination of two phages led to the emergence of phage resistant bacteria. Even so, the use of two phages presented better results than the use of an individual phage. The most important result was the eradication of Salmonella from the samples when the three phage cocktail was inoculated in raw wastewater (Turki et al., 2011).

\subsection{Considerations}

The above studies showed inconsistencies in the ability of phages to act as biocontrol agents of Campylobacter and Salmonella in livestock. Even so, it seems that the proof of principle, that phages are able to reduce the number of these pathogens (at least in a short period after treatment), has been established.

At a first glance, in vivo biocontrol of foodborne pathogens made "on-farm" seems to be a good approach since, theoretically, the problem would be treated on its origin. Ideally, phages would be applied through the use of a sole administration of a low dose of phage. The virulent phage should then amplify at the expense of the target bacteria by repeated cycles of replication leading to the host eradication. The increasing number of the progeny phage would remain in the system for some period of time acting prophylactically in a possible subsequent infection. Although, as shown by several studies, eradication of the target bacteria is an extremely unlikely event in part due to the coexistence of a phage- 


\begin{tabular}{|c|c|c|c|}
\hline $\begin{array}{c}\text { Target } \\
\text { pathogen }\end{array}$ & Foodstuff & Results & References \\
\hline \multirow{3}{*}{ 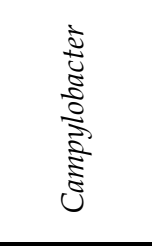 } & chicken skin & $\begin{array}{l}\text { Reduction of up to } 2 \log _{10} \text { on frozen } \\
\text { samples }\end{array}$ & $\begin{array}{l}\text { (Atterbury et } \\
\text { al., 2003a) }\end{array}$ \\
\hline & chicken skin & $\begin{array}{l}\text { Reduction of up to } 2.31 \log _{10} \mathrm{CFU} / \mathrm{g} \text { at } \\
4^{\circ} \mathrm{C} \text {. }\end{array}$ & $\begin{array}{l}\text { (Goode et al., } \\
\text { 2003) }\end{array}$ \\
\hline & $\begin{array}{l}\text { raw and cooked } \\
\text { meat }\end{array}$ & $\begin{array}{l}\text { Reduction of up to } 2.8 \log _{10} \mathrm{CFU} \text { on } \\
\text { cooked meat }\end{array}$ & $\begin{array}{l}\text { (Bigwood et al., } \\
\text { 2008) }\end{array}$ \\
\hline \multirow{9}{*}{ 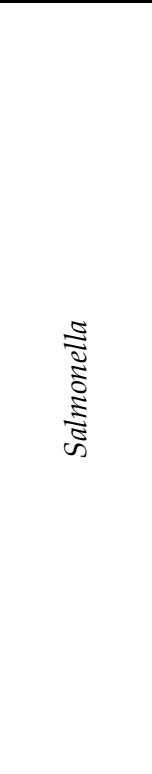 } & chicken skin & $\begin{array}{l}\text { Reduction of up to no recoverable } \\
\text { Salmonella }\end{array}$ & $\begin{array}{l}\text { (Goode } \text { et al., } \\
\text { 2003) }\end{array}$ \\
\hline & pig skin & $\begin{array}{l}\text { Reduction of up to below detectable } \\
\text { levels at } 4^{\circ} \mathrm{C}\end{array}$ & $\begin{array}{l}\text { (Hooton et al., } \\
\text { 2011) }\end{array}$ \\
\hline & $\begin{array}{l}\text { chickens and } \\
\text { turkeys carcasses }\end{array}$ & $\begin{array}{l}\text { Reduction of up to } 93 \% \text { reduction in } \\
\text { Salmonella recovery }\end{array}$ & $\begin{array}{l}\text { (Higgins et al., } \\
\text { 2005) }\end{array}$ \\
\hline & $\begin{array}{l}\text { raw and cooked } \\
\text { meat }\end{array}$ & $\begin{array}{l}\text { Reduction of more than } 5.9 \log _{10} \mathrm{CFU} \text { on } \\
\text { raw meat }\end{array}$ & $\begin{array}{l}\text { (Bigwood et al., } \\
\text { 2008) }\end{array}$ \\
\hline & chicken sausages & $\begin{array}{l}\text { Reduction of up to } 2.1 \log _{10} \text { in the } \\
\text { Salmonella levels }\end{array}$ & $\begin{array}{l}\text { (Whichard et } \\
\text { al., 2003) }\end{array}$ \\
\hline & fresh-cut fruit & $\begin{array}{l}\text { Reduction of up to } 3.5 \log _{10} \text { in Salmonella } \\
\text { numbers in honeydew melon slices } \\
\text { stored at } 5{ }^{\circ} \mathrm{C}\end{array}$ & $\begin{array}{l}\text { (Leverentz et } \\
\text { al., 2001b) }\end{array}$ \\
\hline & sprouting seeds & $\begin{array}{l}\text { Reduction of up to } 1.5 \log _{10} \text { in Salmonella } \\
\text { numbers }\end{array}$ & $\begin{array}{l}\text { (Pao et al., } \\
2004)\end{array}$ \\
\hline & cheese & $\begin{array}{l}\text { Reduction of up to no recoverable } \\
\text { Salmonella in pasteurized milk cheeses }\end{array}$ & $\begin{array}{l}\text { (Modi et al., } \\
\text { 2001) }\end{array}$ \\
\hline & $\begin{array}{l}\text { dairy manure } \\
\text { compost }\end{array}$ & Reduction of up to $3 \log _{10}$ & $\begin{array}{l}\text { (Heringa et al., } \\
\text { 2010) }\end{array}$ \\
\hline
\end{tabular}

Table 2. Studies on phage biocontrol in foodstuff

resistant bacterial subpopulation. Eradication is even difficult in vivo since the number of Salmonella and Campylobacter is usually higher in broiler chicken intestines than in the carcasses and derived products. Moreover, the colonization of animals in herds or flocks spreads exponentially and infection may be through direct contact with pens and holding facilities which were used before by infected animals. Therefore, the on-farm treatment may lead to the emergence of phage resistant strains with their consequent spread to all animals in the farm. In addition, repeatedly use of phages may induce production of antibodies that will afterwards neutralize the phages, diminishing their effectiveness (Johnson et al., 2008). The emergence of phage resistant bacteria is a major concern in phage biocontrol and long term studies on the resistance and resistant bacteria should be performed.

The consistent reduction of the target bacteria shortly after phage administration, and the need to avoid the emergence of phage-resistant strains, suggests that phages should be applied shortly before slaughter. Indeed, in the period preceding slaughter, the animal is an epidemiological endpoint and the phages, as well the bacteria, will be removed from the contaminated source. This will prevent the emergence, spread and establishment of phage- 
resistant strains and will not have an impact on the farm microbial balance. Moreover this approach constitutes a realistic application of phages enabling the administration of a single dose. This will result in a low number of pathogens during food processing with the consequent decrease of cross-contamination, contributing thus to the consumer safety.

Even so, some considerations should be taken into account for an efficient application of phages. Phages can be administered by different routes that will have impact in the efficacy of the phage action but also economic and practical implications. Obviously, the most practical, and probably economical, route of phage application is through food and drinking water, at least for large scale treatments as is the treatment of Salmonella and Campylobacter in the poultry industry. These routes of administrations will require further studies on the dose (volume and concentration) that will be incorporated into food or added to water as well the need for a way to protect phages from the low $\mathrm{pH}$ of the gastrointestinal tract that was shown to often inactivate the majority of phages (Smith et al., 1987a). Protection may be enabled through the simultaneously administration of an antacid or through phage proper encapsulation as tested by Carvalho et al. (2010) with a Campylobacter phage, phiCcoIBB35 (Carvalho et al., 2010a), and Ma et al. (2008) with Salmonella phage Felix 01 (Ma et al., 2008), respectively. Alternatively, higher phage concentrations and/or phage mutants resistant to low $\mathrm{pH}$ may be used to increase the efficacy of phage treatment. Intramuscular inoculation seems only feasible to treat a low number and/or animals which represent an added value. Another important consideration is the need for in vivo studies for each phage in an appropriate model able to mimic the system in which the particular phage is to be administered since in vitro behaviour usually does not reflects the phage behaviour in vivo, in part due to the immune system response. This fact has also been often observed in the above studies.

In the case where phage therapy immediately before slaughter is not possible due to inefficiency or impracticability, treatment of meat and foodstuff is also a possible approach. When phages are applied in foodstuff (post-slaughter), as in the case of a pre-slaughter phage treatment, the emergence of phage-resistant is also prevented since the phages and bacterial populations will be removed from the contamination source. Some studies, as described above, have addressed the possibility of using phages in the control of foodborne pathogens in foodstuff although, the majority of the Salmonella studies were carried at a temperature that is the optimum for the target bacteria to grow. This may lead to erroneous phage efficacy assessment because phage behaviour is highly dependent on the bacterial physiology which in turn also depends on the temperature. Consequently, a reliable study should be carried at the same temperature and other conditions at which the foodstuff is prepared, processed and/or stored. Commercial storage conditions of carcasses, meat and other foodstuff often include a refrigerated temperature of $4^{\circ} \mathrm{C}$ in order to halt bacterial growth. Experiments performed at this temperature with Campylobacter and Salmonella have shown that a relative high dose (high MOI) of phage is needed probably due to the reduced host growth that will prevent phage replication. Even so, this is not much different from what was observed at higher temperatures or even in studies in livestock where, as it is shown here, a high MOI seems to be a requirement to reduce pathogenic loads. The presented studies have shown that little or no reduction was observed for MOIs of 1 or less suggesting that the therapeutic effect of the phages is passive, without taking advantage of their replicating and self-amplification ability. This passive effect of phages is known as 
"lysis from without" in which the adsorption and attachment of many phages to the bacterial surface of a single cell results in lysis without phage replication. The passive effect is corroborated by the results of Bigwood et al. (2008) who found that phages did not increase in numbers after reducing the Salmonella counts. This passive effect performed by the phages is not impaired at temperatures below the minimum for bacterial host growth as seen in these experiments performed at $4^{\circ} \mathrm{C}$ and $5^{\circ} \mathrm{C}$ reinforcing phage application in foodstuff at storage conditions (Atterbury et al., 2003a; Bigwood et al., 2008). Moreover, this passive effect seems to be less specific than the active one (where phages replicate inside their host) as has been observed by Goode et al. (2003) where Salmonella strains resistant to phage through restriction were also eliminated by passive effect of phages as long as the phages were able to attach (Goode et al., 2003). Consequently, treatment with high MOIs, although economically not so attractive due to the need of a higher dose, are able to reduce the emergence of phage-resistant strains.

Another requirement of phage biocontrol is the need for broad host range phages and/or the use of a cocktail. Higher reductions in pathogenic bacteria were consistently obtained in livestock and foodstuff when a cocktail of phages with complementary host ranges and target receptors were used. The advantages of using cocktails and broad host range phages will be discussed below.

Risk analysis modelling have shown that a reduction of $2 \log _{10}$ in faeces of the slaughtered animal or in chicken carcasses can reduce the risk to consumers in $75 \%$ or 30 times respectively, in the incidence of campylobacteriosis associated with chickens consumption (Havelaar et al., 2007; Rosenquist et al., 2003). This $2 \log _{10}$ reduction was shown in these studies to be a possible, practical and realistic goal.

It can thus be concluded that (by using broad host range phages or cocktails of phages with a broad lytic spectrum, applied at high MOI, complemented with in vivo studies) both approaches (phage biocontrol in livestock at pre slaughter and in foodstuff) can be used in order to decrease the number of pathogenic bacteria in the food chain and consequently to reduce the incidence of foodborne diseases caused by Campylobacter and Salmonella. Although the studies only address the use of these two strategies separately, and because their effectiveness relies in the passive ability of phages to lyse the cells (and thus do not depends on the host concentration and physiological state), it can be argued that both approaches can be used together in order to achieve higher reductions of the pathogenic bacterial loads.

\section{Prerequisites for an acceptable phage product}

The better understanding of phage biology, infectious process and host-range specificity has been tracing the path by which the problems with early phage research may be partially or totally solved. Therefore the knowledge acquired so far coupled with the awareness of the mistakes committed, should be used to develop phage preparations which should meet several criteria whether they are intended to be applied in foodstuff or more importantly in animals and humans. Newly isolated phages should always be characterized in detail and biocontrol should not be attempted before the biology and genomics of the therapeutic phage is well understood. Consequently, the phage host range, virulence, stability and interaction with both innate and active immune systems should be determined. 


\subsection{Lytic phages}

In order to assure safety of phage therapy and eliminate potential risks of failure or even complications, it is critical that phages used in therapy are strictly lytic and without: transducing capabilities, gene sequences having significant homology with known major antibiotic resistance genes, genes for toxins and genes for other bacterial virulence factors (Carlton et al., 2005). Consequently, it is critical to avoid temperate phages. Reasons for this discrimination involve the fact that the latter phages will not kill all the target bacteria due to their ability to lysogenize them and probably more important, there is a high risk of possessing genes that can render the bacteria more virulent (Los et al., 2010). This can happen because certain temperate phages, such as those associated with Staphylococcus, E. coli, Salmonella, Corynebacterium and Clostridium actually carry virulence genes. In addition, during the transition between the lysogenic cycle and the lytic cycle, the excision of the prophage DNA may be accompanied with small pieces of the bacterial genome thus producing a specialized transducing phage. In addition, certain viruses such as Salmonella phage P22 are generalized transducers that are capable of randomly packaging any part of the host genome. Transducing phages will then transfer the host DNA fragments to newly infected bacteria producing changes in the bacterial genomes through recombination or reintegration. This may produce undesired phenotypic changes in their hosts such as resistance to antibiotics, restriction systems and increased bacterial virulence such as: bacterial adhesion, colonization, invasion and spread through human tissues, resistance to immune defences and exotoxin production (e.g. cholera toxin encoded by Vibrio choleraephage CTX) (Los et al., 2010; Waldor \& Mekalanos, 1996). Strictly lytic phages usually do not pose these risks but should be tested for transducing (Waddell et al., 2009).

\subsection{Cocktails and broad-host-range phages}

Within a given bacterial pathogen different mutants may exist with different susceptibility for a given phage. Although therapy should always match the phage with the target bacteria there are situations where treatment is urgently need, turning that approach impossible. Moreover, bacterial pathogens may mutate during the treatment time period and become resistant to the phage. This risk is real in part due to the narrow host range of phages. A way to circumvent these problems is by using a cocktail of phages targeting different receptors in the pathogen cell and with cross-resistant lytic activity. Consequently, if a bacterium is, or stays, resistant to one phage it is likely that it would not be resistant to a second phage which is immediately available in the cocktail and that targets a different receptor. This approach has been successfully used by Smith et al. (1987) in their E. coli diarrhoeal work (Smith et al., 1987b).

An alternative to the phage cocktails is the use of broad host range phages that can be isolated through the use of common ubiquitous receptors in the target bacteria as in the case of phages that recognize TolC. In Salmonella this outer membrane protein is involved in the adhesion and invasion of host intestinal epithelial cells (Ricci \& Piddock, 2010). Broad host range phages are polyvalent phages capable of infecting across bacterial species or genera and thus able to infect the majority of the target bacteria. These phages present a huge advantage as therapeutic agents and from the biotechnological point of view they are much more attractive because a single phage is far easier to characterize and get approved by the regulatory authorities. The existence of such polyvalent phages in nature is rare and only a 
few of them are known. Examples include Salmonella phage Felix O1 which infects most Salmonella serovars (Kallings, 1967) and Salmonella phage PVP-SE1 which presents a lytic spectrum even broader than that of Felix 01 (Santos et al., 2010). Nevertheless these phages may present a drawback if they are able to target other non-pathogenic bacteria causing dysbiosis. Therefore the ideal phage for use as biocontrol agent should have a broad host range among the target pathogen without infecting the commensal flora. Examples of these phages include two virulent coliphages which were able to lyse a high percentage of pathogenic E. coli strains of various serotypes whilst showed low lytic ability to lyse nonpathogenic E. coli strains (Viscardi et al., 2008). These broad host range phages may also be used, not only as alternatives to cocktails, but also to design new cocktails with broader host ranges and consequently more efficient. Furthermore, phage cocktails and broad host range phages will also combat and prevent the emergence of phage resistant strains. Another possibility would be to engineer phages in order to target numerous receptors. Although very interesting and promising from a scientific point of view, this approach would hardly get acceptance from the food authorities (Kropinski, 2006).

\subsection{Genome sequencing}

A full knowledge of phage genome sequences is important to ensure that the phage does not carry obvious virulence factors, resistance or lysogeny genes. The identification of gene homologies requires detailed bioinformatics analysis. The latter is essential to evaluate possible complications that might arise during phage therapy. It was suggested that data from phage genome sequences could be used to establish a bank of "safe" therapeutic phages increasing the availability, safety and efficacy of phage therapy (Petty et al., 2007).

Phages that break down the bacterial DNA to recycle bacterial host genome for their own DNA synthesis should be selected for therapy since this will hamper coexistence between phage and host. Such phages usually encode enzymes involved in nucleotide metabolism and the corresponding genes can be identified through sequence analysis (Carlton et al., 2005). Even so, due to the usually high number of genes in the phage genome with unknown function, it is never possible to assure at $100 \%$ that no virulence factors, resistance or lysogeny genes exist. Correspondingly, the genome sequencing analysis enables to reject the use of phages for which genes were found to code for virulence, resistance or lysogeny but that does not present any experimental biologic evidence of it, that is, which never have shown to lysogenize a bacterium or increase the bacterium virulence and/or resistance.

\subsection{Models for host-phage interaction}

Phage therapy experimental design is not straightforward due to the self-replicating nature of phages. This means that for each phage, pharmacokinetic information is required which can be achieved by the determination of the phage infection parameters and by the use of a reliable population dynamic model able to predict the phage-bacteria behaviour. Understanding these dynamics will help the transference of in vitro results to in vivo predictions, explaining why a phage that replicates extremely well in the target bacteria in vitro fails to do it in vivo. It is expected that mathematical models may help to design experimental studies of population dynamics by identifying and evaluating the relative contribution of phage and bacteria in the course and outcome of an infection (Levin \& Bull, 2004). Therefore, in vivo assessment of the phage, in a suitable animal model, should always be accomplished. 


\subsection{Phage production in a large-scale and storage}

The increasing interest in phages as therapeutic or biocontrol agents and the intention of commercially distribute a phage or a phage based product demands a large scale production that is not compatible with the conventional double-agar overlay method. Consequently, production of phages will certainly make use of bioreactors and a control and optimization of phage production will play an important role. Good manufacturing practice requirements demands for the development of methods that ensure phage preparations highly purified, free of bacteria, toxins, pyrogenic substances and other harmful components. Although in the majority of animal studies phages were administered as crude lysates without adverse effects for the animal, the removal of endotoxins, exotoxins and cell debris is very important for the safety of the phage product and also for an easier acceptance by the consumers. An option would be the propagation of phages in a non-pathogenic or in a non-toxin producer host (Santos et al., 2010). The storage should also be validated and suitable for the particular phage in order to assure that the preparations contain viable phage particles able to infect the target bacteria. Moreover, stability and $\mathrm{pH}$ control of the preparation is important as shown in the past by the rising problems observed when these facts were neglected (Merabishvili et al., 2009).

\section{Commercialization of phage-based products}

Despite the good scientific results and the economic viability of phage products an important issue that cannot be forgotten is the public acceptance which can constitute a serious obstacle to the introduction of phages in food. It is likely that consumers will feel an antipathy when knowing that live viruses are being added in their foods and that will be ingested by them. First of all, phages are viruses that only infect bacteria and not eukaryotic cells as the human cells. Moreover they are very specific to the target bacteria avoiding this way dysbiosis. It is also important to note that the use of a virus to combat a pathogen is not so strange since some vaccinations are carried out using live, albeit attenuated, eukaryotic viruses. Since phages have been identified in drinking water, and foods such a yoghurt and salami they are generally considered safe (Rohwer, 2003). Also, this means not only that phages are already inside our body but also that they are constantly being ingested. Different phages, applied at different doses, using different routes of administration in humans during the long history of phage therapy in the Eastern Europe did not produced serious complications (Sulakvelidze et al., 2001). Moreover, in a carefully controlled doubleblind study involving ingestion of phage T4 by volunteers, no side effects were reported (Bruttin \& Brussow, 2005). These facts show that phages are nontoxic to animals and plants and apparently innocuous from a clinical standpoint. Along these lines, it can be conclude that the introduction of phages in human food-chain through the usage of phages as biocontrol agents in living animals or carcases can be considered safe and may be seen as a valuable alternative to the use of antibiotics in animal production.

With respect to regulations, the introduction of a biocontrol phage product in animals and foodstuff may not be as stringent as its introduction in human therapy. The way for its introduction has been recently (2006) paved by the approval by the American Food and Drug Administration (FDA) of a mixed Listeria-phage preparation, ListShield (www.intralytix.com) to be used as a food additive in poultry derivatives and ready-to-eat meat. Another product based on a Listeria-phage, Listex P-100 (www.micreosfoodsafety.com), has received the status 
"generally recognized as safe" (GRAS) to be used in all food products in 2007. Other phagebased products to control E. coli and Salmonella exist to be used at pre-slaughter (www.omnilytics.com and www.intralytix.com). The approval of such products proves the safety of phages and anticipates the development and introduction of new phage based products to be applied not only in foodstuff but also, at a long term, in animals and humans.

\section{Conclusions}

The emergence of multidrug-resistant bacteria has opened a second window for phage biocontrol. The recent work reviewed here shows that it has been established the proof-ofprinciple and evidences are more than enough to state that phage biocontrol, if wellconceived, is very effective in the treatment and prophylaxis of many problematic infectious diseases. Of particular interest is the potential that phage biocontrol has demonstrated against the global problematic multidrug-resistant bacteria. While the results of phage based products efficacy are very promising some consideration need to be taken into account. Efficient phage biocontrol requires the use of broad host range phages and administration of cocktails of phages with complementary host ranges and target receptors (showing thus cross-resistant lytic activity) in order to circumvent the emergence of phage resistant bacteria. Also, in vivo studies with suitable models should always be performed to assess the efficacy of the phage based product. From an economical and practical point of view, the best route of administration at an industrial scale is obviously through food and drinking water. For a successful application of phages it is important to understand the epidemiology of the pathogen against which the phage preparation is to be used in order to identify the critical intervention points in the processing cycle where phage application would be most beneficial. On the other hand, consistent pathogenic bacteria reduction is only achieved short after phage administration suggesting that phages should be applied in livestock shortly before slaughter and/or post-slaughter in carcasses and foodstuff. Besides reducing significantly the bacterial loads in the food chain with the consequent reduction in foodborne incidences it will impair the emergence of phage resistant bacteria.

Finally, although the consumers may be reluctant to the introduction of phages in the food chain, they have already shown to be safe for the environment, animals and humans with high efficiency in the reduction of foodborne pathogens. Moreover, some phage products are already commercially available and thus the way for the introduction of new phage based products is now open.

Overall, it can be concluded that phages can and should be used, not only as alternative, but also as substitutes of antibiotics and chemical antibacterials, in the control of foodborne pathogens in livestock and foodstuff.

\section{References}

Aarestrup, F. M., Wegener, H. C., \& Collignon, P. (2008). Resistance in bacteria of the food chain: epidemiology and control strategies. Expert review of anti-infective therapy, Vol. 6, No. 5, pp. 733-750.

Aarestrup, F. M., Seyfarth, A. M., Emborg, H. D., Pedersen, K., Hendriksen, R. S., \& Bager, F. (2001). Effect of abolishment of the use of antimicrobial agents for growth promotion on occurrence of antimicrobial resistance in fecal enterococci from food 
animals in Denmark. Antimicrobial Agents and Chemotherapy, Vol. 45, No. 7, pp. 2054-2059.

Ackermann, H. W. (2001). Frequency of morphological phage descriptions in the year 2000. Brief review. Archives of Virology, Vol. 146, No. 5, pp. 843-857.

Ackermann, H. W. (2007). Salmonella Phages Examined in the Electron Microscope, In: Methods in Molecular Biology, pp. 213-234.

Ackermann, H. W. (2009). Phage Classification and Characterization, In: Bacteriophages Methods and Protocols, A. M. Kropinski \& M. Clookie, pp. 127-140, Humana Press.

Allen, V. M., Bull, S. A., Corry, J. E. L., Domingue, G., Jorgensen, F., Frost, J. A., Whyte, R., Gonzalez, A., Elviss, N., \& Humphrey, T. J. (2007). Campylobacter spp. contamination of chicken carcasses during processing in relation to flock colonisation. International Journal of Food Microbiology, Vol. 113, No. 1, pp. 54-61.

Andreatti Filho, R. L., Higgins, J. P., Higgins, S. E., Gaona, G., Wolfenden, A. D., Tellez, G., \& Hargis, B. M. (2007). Ability of bacteriophages isolated from different sources to reduce Salmonella enterica serovar enteritidis in vitro and in vivo. Poultry science, Vol. 86, No. 9, pp. 1904-1909.

Antunes, P., Reu, C., Sousa, J. C., Peixe, L., \& Pestana, N. (2003). Incidence of Salmonella from poultry products and their susceptibility to antimicrobial agents. International Journal of Food Microbiology, Vol. 82, No. 2, pp. 97-103.

Atterbury, R. J., Connerton, P. L., Dodd, C. E., Rees, C. E., \& Connerton, I. F. (2003a). Application of host-specific bacteriophages to the surface of chicken skin leads to a reduction in recovery of Campylobacter jejuni. Applied and Environmental Microbiology, Vol. 69, No. 10, pp. 6302-6306.

Atterbury, R. J., Connerton, P. L., Dodd, C. E., Rees, C. E., \& Connerton, I. F. (2003b). Isolation and characterization of Campylobacter bacteriophages from retail poultry. Applied and Environmental Microbiology, Vol. 69, No. 8, pp. 4511-4518.

Atterbury, R. J., Dillon, E., Swift, C., Connerton, P. L., Frost, J. A., Dodd, C. E., Rees, C. E., \& Connerton, I. F. (2005). Correlation of Campylobacter bacteriophage with reduced presence of hosts in broiler chicken ceca. Applied and Environmental Microbiology, Vol. 71, No. 8, pp. 4885-4887.

Atterbury, R. J., Van Bergen, M. A., Ortiz, F., Lovell, M. A., Harris, J. A., De Boer, A., Wagenaar, J. A., Allen, V. M., \& Barrow, P. A. (2007). Bacteriophage therapy to reduce Salmonella colonization of broiler chickens. Applied and Environmental Microbiology, Vol. 73, No. 14, pp. 4543-4549.

Atterbury, R. J. (2009). Bacteriophage biocontrol in animals and meat products. Microbial Biotechnology, Vol. 2, No. 6, pp. 601-612.

Bell, C. \& Kyriakides, A. (2002). Salmonella, In: Foodborne Pathogens: Hazards, Risk Analysis and Control, C. W. Blackburn \& P. J. McClure, pp. 307-335, CRC Press.

Berchieri, A. J., Lovell, M. A., \& Barrow, P. A. (1991). The activity in the chicken alimentary tract of bacteriophages lytic for Salmonella typhimurium. Research in Microbiology, Vol. 142, No. 5, pp. 541-549.

Berndtson, E., Tivemo, M., \& Engvall, A. (1992). Distribution and numbers of Campylobacter in newly slaughtered broiler chickens and hens. International Journal of Food Microbiology, Vol. 15, No. 1-2, pp. 45-50. 
Bigwood, T. \& Hudson, J. a. (2009). Campylobacters and bacteriophages in the surface waters of Canterbury (New Zealand). Letters in applied microbiology, Vol. 48, No. 3, pp. 343-348.

Bigwood, T., Hudson, J. a., Billington, C., Carey-Smith, G. V., \& Heinemann, J. a. (2008). Phage inactivation of foodborne pathogens on cooked and raw meat. Food Microbiology, Vol. 25, No. 2, pp. 400-406.

Borie, C., Albala, I., Sànchez, P., Sánchez, M. L., Ramírez, S., Navarro, C., Morales, M. A., Retamales, J., \& Robeson, J. (2008). Bacteriophage Treatment Reduces Salmonella Colonization of Infected Chickens. Avian Diseases, Vol. 52, No. 1, pp. 64-67.

Borie, C., Sanchez, M. L., Navarro, C., Ramirez, S., Morales, M. A., Retamales, J., \& Robeson, J. (2009). Aerosol spray treatment with bacteriophages and competitive exclusion reduces Salmonella enteritidis infection in chickens. Avian Diseases, Vol. 53, No. 2, pp. 250-254.

Brenner, F. W., Villar, R. G., Angulo, F. J., Tauxe, R., \& Swaminathan, B. (2000). Salmonella nomenclature. Journal of Clinical Microbiology, Vol. 38, No. 7, pp. 2465-2467.

Bruttin, A. \& Brussow, H. (2005). Human volunteers receiving Escherichia coli phage T4 orally: a safety test of phage therapy. Antimicrobial Agents and Chemotherapy, Vol. 49, No. 7, pp. 2874-2878.

Bryan, F. L. \& Doyle, M. P. (1995). Health risks and consequences of Salmonella and Campylobacter jejuni in raw poultry. Journal of Food Protection, Vol. 58, No. 3, pp. 326344.

Butzler, J. P. (2004). Campylobacter, from obscurity to celebrity. Clinical microbiology and infection, Vol. 10, No. 10, pp. 868-876.

Carlton, R. M., Noordman, W. H., Biswas, B., de Meester, E. D., \& Loessner, M. J. (2005). Bacteriophage P100 for control of Listeria monocytogenes in foods: genome sequence, bioinformatic analyses, oral toxicity study, and application. Regulatory Toxicology and Pharmacology, Vol. 43, No. 3, pp. 301-312.

Carvalho, C., Gannon, B., Halfhide, D., Santos, S., Hayes, C., Roe, J., \& Azeredo, J. (2010a). The in vivo efficacy of two administration routes of a phage cocktail to reduce numbers of Campylobacter coli and Campylobacter jejuni in chickens. BMC Microbiology, Vol. 10, pp. 232-.

Carvalho, C., Susano, M., Fernandes, E., Santos, S., Gannon, B., Nicolau, A., Gibbs, P., Teixeira, P., \& Azeredo, J. (2010b). Method for bacteriophage isolation against target Campylobacter strains. Letters in applied microbiology, Vol. 50, No. 2, pp. $192-$ 197.

Carvalho, C. M., Kropinski, A. M., Lingohr, E. J., Santos, S. B., King, J., \& Azeredo, J. (2011). The genome and proteome of a Campylobacter coli bacteriophage vB_CcoM-IBB_35 reveal unusual features. Virology Journal, Vol. In Press.

Castanon, J. I. (2007). History of the use of antibiotic as growth promoters in European poultry feeds. Poultry science, Vol. 86, No. 11, pp. 2466-2471.

Chan, K. F., Le, T. H., Kanenaka, R. Y., \& Kathariou, S. (2001). Survival of clinical and poultry-derived isolates of Campylobacter jejuni at a low temperature (4 degrees C). Applied and Environmental Microbiology, Vol. 67, No. 9, pp. 4186-4191.

Chen, H. C. \& Stern, N. J. (2001). Competitive exclusion of heterologous Campylobacter spp. in chicks. Applied and Environmental Microbiology, Vol. 67, No. 2, pp. 848-851. 
Connerton, I. F., Connerton, P. L., , B. P., , S. B. S., \& Atterbury, R. J. (2008). Bacteriophage therapy and Campylobacter, In: Campylobacter, I. Nachamkin \& M. J. Blaser, pp. 679693, American Society for Microbiology, Washington, D.C..

Connerton, P. L., Loc Carrillo, C. M., Swift, C., Dillon, E., Scott, A., Rees, C. E., Dodd, C. E., Frost, J., \& Connerton, I. F. (2004). Longitudinal study of Campylobacter jejuni bacteriophages and their hosts from broiler chickens. Applied and Environmental Microbiology, Vol. 70, No. 7, pp. 3877-3883.

Connerton, P. L., Timms, A. R., \& Connerton, I. F. (2011). Campylobacter bacteriophages and bacteriophage therapy. Journal of Applied Microbiology, Vol. 111, No. 2, pp. 255-265.

Corry, J. E. \& Atabay, H. I. (2001). Poultry as a source of Campylobacter and related organisms. Symposium series (Society for Applied Microbiology), Vol. 30, pp. 96S-114S.

Dabrowska, K., Switala-Jelen, K., Opolski, A., Weber-Dabrowska, B., \& Gorski, A. (2005). Bacteriophage penetration in vertebrates. Journal of Applied Microbiology, Vol. 98, No. 1, pp. 7-13.

Doyle, M. P. \& Erickson, M. C. (2006). Reducing the carriage of foodborne pathogens in livestock and poultry. Poultry science, Vol. 85, No. 6, pp. 960-973.

El-Shibiny, A., Scott, A., Timms, A., Metawea, Y., Connerton, P., \& Connerton, I. (2009). Application of a group II Campylobacter bacteriophage to reduce strains of Campylobacter jejuni and Campylobacter coli colonizing broiler chickens. Journal of Food Protection, Vol. 72, No. 4, pp. 733-740.

El-Shibiny, A., Connerton, P. L., \& Connerton, I. F. (2005). Enumeration and diversity of campylobacters and bacteriophages isolated during the rearing cycles of free-range and organic chickens. Applied and Environmental Microbiology, Vol. 71, No. 3, pp. 1259-1266.

Emborg, H. D., Andersen, J. S., Seyfarth, A. M., Andersen, S. R., Boel, J., \& Wegener, H. C. (2003). Relations between the occurrence of resistance to antimicrobial growth promoters among Enterococcus faecium isolated from broilers and broiler meat. International Journal of Food Microbiology, Vol. 84, No. 3, pp. 273-284.

European Food Safety Authority (2006). The Community Summary Report on Trends and Sources of Zoonoses, Zoonotic Agents, Antimicrobial Resistance and Foodborne Outbreaks in the European Union in 2005. The EFSA Journal, Vol. 94, pp. 2-288.

European Food Safety Authority (2009). The Community Summary Report on Trends and Sources of Zoonoses and Zoonotic Agents in the European Union in 2007. The EFSA Journal, Vol. 223, pp. 1-320.

European Food Safety Authority (2010). The Community Summary Report on Trends and Sources of Zoonoses, Zoonotic Agents and Food-borne Outbreaks in the European Union in 2008. EFSA Journal, Vol. 8, pp. 1-410.

European Food Safety Authority (2011). The European Union Summary Report on Trends and Sources of Zoonoses, Zoonotic Agents and Food-borne Outbreaks in 2009. The EFSA Journal, Vol. 9, pp. 1-378.

European Food Safety Authority \& European Centre for Disease Prevention and Control (2011). European Union summary report on antimicrobial resistance in zoonotic and indicator bacteria from animals and food in the European Union in 2009. EFSA Journal, Vol. 9, pp. 1-321. 
Fiorentin, L., Vieira, N. D., \& Barioni, W. (2005). Oral treatment with bacteriophages reduces the concentration of Salmonella Enteritidis PT4 in caecal contents of broilers. Avian pathology, Vol. 34, No. 3, pp. 258-263.

Friedman, C. R., Neimann, J., , W. H. C., \& Tauxe, R. V. (2000). Epidemiology of Campylobacter jejuni infections in the United States and other industrialzed nations, In: Campylobacter, I. Nachamkin \& M. J. Blaser, pp. 121-138, American Society for Microbiology, Washington, D.C..

Frost, J. A., Kramer, J. M., \& Gillanders, S. a. (1999). Phage typing of Campylobacter jejuni and Campylobacter coli and its use as an adjunct to serotyping. Epidemiology and infection, Vol. 123, No. 1, pp. 47-55.

García, P., Martínez, B., Obeso, J. M., \& Rodríguez, a. (2008). Bacteriophages and their application in food safety. Letters in applied microbiology, Vol. 47, No. 6, pp. 479-485.

Goode, D., Allen, V. M., \& Barrow, P. A. (2003). Reduction of Experimental Salmonella and Campylobacter Contamination of Chicken Skin by Application of Lytic Bacteriophages. Applied and Environmental Microbiology, Vol. 69, No. 8, pp. 50325036.

Goodridge, L. \& Abedon, S. T. (2003). Bacteriophage biocontrol and bioprocessing: Application of phage therapy to industry. Society for Industrial Microbiology News, Vol. 53, No. 6, pp. 254-262.

Gorman, R., Bloomfield, S., \& Adley, C. C. (2002). A study of cross-contamination of foodborne pathogens in the domestic kitchen in the Republic of Ireland. International Journal of Food Microbiology, Vol. 76, No. 1-2, pp. 143-150.

Greer, G. G. (1988). Effects of Phage Concentration, Bacterial Density, and Temperature on Phage Control of Beef Spoilage. Journal of Food Science, Vol. 53, No. 4, pp. 1226-1227.

Guttman, B., Raya, R., \& Kutter, E. (2005). Basic Phage Biology, In: Bacteriophages. Biology and applications., E. Kutter \& A. Sulakvelidze, CRC Press.

Gyles, C. L. (2008). Antimicrobial resistance in selected bacteria from poultry. Animal Health Research Reviews, Vol. 9, No. 2, pp. 149-158.

Hagens, S. \& Loessner, M. J. (2010). Bacteriophage for biocontrol of foodborne pathogens: calculations and considerations. Current Pharmaceutical Biotechnology, Vol. 11, No. 1, pp. 58-68.

Hammerl, J. A., Jackel, C., Reetz, J., Beck, S., Alter, T., Lurz, R., Barretto, C., Brussow, H., \& Hertwig, S. (2011). Campylobacter jejuni group III phage CP81 contains many T4-like genes without belonging to the T4-type phage group: implications for the evolution of T4 phages. Journal of Virology, Vol. 85, No. 17, pp. 8597-8605.

Hansen, V. M., Rosenquist, H., Baggesen, D. L., Brown, S., \& Christensen, B. B. (2007). Characterization of Campylobacter phages including analysis of host range by selected Campylobacter Penner serotypes. BMC Microbiology, Vol. 7, pp. 90-.

Hansson, I., Ederoth, M., Andersson, L., Vågsholm, I., \& Olsson Engvall, E. (2005). Transmission of Campylobacter spp. to chickens during transport to slaughter. Journal of Applied Microbiology, Vol. 99, No. 5, pp. 1149-1157.

Havelaar, A. H., Mangen, M. J., de Koeijer, A. A., Bogaardt, M. J., Evers, E. G., JacobsReitsma, W. F., van, P. W., Wagenaar, J. A., de Wit, G. A., van der, Z. H., \& Nauta, M. J. (2007). Effectiveness and efficiency of controlling Campylobacter on broiler chicken meat. Risk Analysis, Vol. 27, No. 4, pp. 831-844. 
Heringa, S. D., Kim, J., Jiang, X., Doyle, M. P., \& Erickson, M. C. (2010). Use of a mixture of bacteriophages for biological control of Salmonella enterica strains in compost. Applied and Environmental Microbiology, Vol. 76, No. 15, pp. 5327-5332.

Higgins, J. P., Higgins, S. E., Guenther, K. L., Huff, W., Donoghue, A. M., Donoghue, D. J., \& Hargis, B. M. (2005). Use of a specific bacteriophage treatment to reduce Salmonella in poultry products. Poultry science, Vol. 84, No. 7, pp. 1141-1145.

Hooton, S. P., Atterbury, R. J., \& Connerton, I. F. (2011). Application of a bacteriophage cocktail to reduce Salmonella Typhimurium U288 contamination on pig skin. International Journal of Food Microbiology, Vol. 151, No. 2, pp. 157-163.

Jacobs-Reitsma, W. (2000). Campylobacter in the food supply, In: Campylobacter, I. Nachamkin \& M. Blaser, ASM Press, Washington DC.

Joerger, R. D. (2001). Alternatives to Antibiotics : Bacteriocins, Antimicrobial Peptides and Bacteriophages. Poultry science, Vol. 82, No. 4, pp. 640-647.

Johannessen, G. S., Johnsen, G., Okland, M., Cudjoe, K. S., \& Hofshagen, M. (2007). Enumeration of thermotolerant Campylobacter spp. from poultry carcasses at the end of the slaughter-line. Letters in applied microbiology, Vol. 44, No. 1, pp. 92-97.

Johnson, R. P., Gyles, C. L., Huff, W. E., Ojha, S., Huff, G. R., Rath, N. C., \& Donoghue, a. M. (2008). Bacteriophages for prophylaxis and therapy in cattle, poultry and pigs. Animal Health Research Reviews, Vol. 9, No. 2, pp. 201-215.

Kallings, L. O. (1967). Sensitivity of various salmonella strains to felix 0-1 phage. Acta pathologica et microbiologica Scandinavica, Vol. 70, No. 3, pp. 446-454.

Keener, K. M., Bashor, M. P., Curtis, P. A., Sheldon, B. W., \& Kathariou, S. (2004). Comprehensive Review of Campylobacter and Poultry Processing. Comprehensive Reviews In Food Science And Food Safety, Vol. 3, No. 2, pp. 105-116.

Kropinski, A. M. (2006). Phage therapy - everything old is new again. Canadian Journal of Infectious Diseases \& Medical Microbiology, Vol. 17, No. 5, pp. 297-306.

Kropinski, A. M., Arutyunov, D., Foss, M., Cunningham, A., Ding, W., Singh, A., Pavlov, A. R., Henry, M., Evoy, S., Kelly, J., \& Szymanski, C. M. (2011). The genome and proteome of Campylobacter jejuni bacteriophage NCTC 12673. Applied and Environmental Microbiology, Vol. In Press.

Kropinski, A. M., Sulakvelidze, A., Konczy, P., \& Poppe, C. (2007). Salmonella phages and prophages--genomics and practical aspects. Methods in Molecular Biology, Vol. 394, pp. 133-175.

Leverentz, B., Conway, W. S., Alavidze, Z., Janisiewicz, W. J., Fuchs, Y., Camp, M. J., Chighladze, E., \& Sulakvelidze, A. (2001b). Examination of bacteriophage as a biocontrol method for salmonella on fresh-cut fruit: a model study. Journal of Food Protection, Vol. 64, No. 8, pp. 1116-1121.

Leverentz, B., Conway, W. S., Alavidze, Z., Janisiewicz, W. J., Fuchs, Y., Camp, M. J., Chighladze, E., \& Sulakvelidze, A. (2001a). Examination of bacteriophage as a biocontrol method for salmonella on fresh-cut fruit: a model study. Journal of Food Protection, Vol. 64, No. 8, pp. 1116-1121.

Levin, B. R. \& Bull, J. J. (2004). Population and evolutionary dynamics of phage therapy. Nature Reviews Microbiology, Vol. 2, No. 2, pp. 166-173.

Loc Carrillo, C., Atterbury, R. J., Connerton, P. L., Dillon, E., Scott, A., \& Connerton, I. F. (2005). Bacteriophage Therapy To Reduce Campylobacter jejuni Colonization of 
Broiler Chickens. Applied and Environmental Microbiology, Vol. 71, No. 11, pp. 65546563.

Los, M., Kuzio, J., McConnell, M., Kropinski, A., Wegrzyn, G., \& Christie, G. (2010). Lysogenic conversion in bacteria of importance to the food industry, In: Bacteriophages in the Detection and Control of Foodborne Pathogens, P. Sabour \& M. Griffiths, pp. 157-198, ASM Press, Washington, DC..

Luber, P., Brynestad, S., Topsch, D., Scherer, K., \& Bartelt, E. (2006). Quantification of Campylobacter Species Cross-Contamination during Handling of Contaminated Fresh Chicken Parts in Kitchens. Applied and Environmental Microbiology, Vol. 72, No. 1, pp. 66-70.

Ma, Y., Pacan, J. C., Wang, Q., Xu, Y., Huang, X., Korenevsky, A., \& Sabour, P. M. (2008). Microencapsulation of bacteriophage felix $\mathrm{O} 1$ into chitosan-alginate microspheres for oral delivery. Applied and Environmental Microbiology, Vol. 74, No. 15, pp. 47994805 .

Marks, T. \& Sharp, R. (2000). Bacteriophages and biotechnology: a review. Journal of Chemical Technology and Biotechnology, Vol. 75, No. 1, pp. 6-17.

Mathew, A. G., Cissell, R., \& Liamthong, S. (2007). Antibiotic resistance in bacteria associated with food animals: a United States perspective of livestock production. Foodborne Pathogens and Disease, Vol. 4, No. 2, pp. 115-133.

Matsuzaki, S., Rashel, L., Uchiyama, J., Sakurai, S., Ujihara, T., Kuroda, M., Ikeuchi, M., Tani, T., Fujieda, M., Wakiguchi, H., \& Imai, S. (2009). Bacteriophage therapy: a revitalized therapy against bacterial infectious diseases. Journal of Infection and Chemotherapy, Vol. 11, No. 5, pp. 211-219.

Mellon, M., Benbrook, C., \& Benbrook, K. L. (2001). Hogging It: Estimates of Antimicrobial Abuse in Livestock,Union of Concerned Scientists, pp. pp. 1-67.

Merabishvili, M., Pirnay, J. P., Verbeken, G., Chanishvili, N., Tediashvili, M., Lashkhi, N., Glonti, T., Krylov, V., Mast, J., Van, P. L., Lavigne, R., Volckaert, G., Mattheus, W., Verween, G., De, C. P., Rose, T., Jennes, S., Zizi, M., De, V. D., \& Vaneechoutte, M. (2009). Quality-controlled small-scale production of a well-defined bacteriophage cocktail for use in human clinical trials. PLoS One., Vol. 4, No. 3, pp. e4944-.

Modi, R., Hirvi, Y., Hill, A., \& Griffiths, M. W. (2001). Effect of phage on survival of Salmonella enteritidis during manufacture and storage of cheddar cheese made from raw and pasteurized milk. Journal of Food Protection, Vol. 64, No. 7, pp. 927-933.

Moran, A. P. \& Upton, M. E. (1987). Factors affecting production of coccoid forms by Campylobacter jejuni on solid media during incubation. Journal of Applied Microbiology, Vol. 62, No. 6, pp. 527-537, 1365-2672 .

Nachamkin, I. (2002). Chronic effects of Campylobacter infection. Microbes and infection, Vol. 4, No. 4, pp. 399-403.

Newell, D. G. \& Fearnley, C. (2003). Sources of Campylobacter Colonization in Broiler Chickens. Applied and Environmental Microbiology, Vol. 69, No. 8, pp. 4343-4351.

Nyachuba, D. G. (2010). Foodborne illness: is it on the rise? Nutrition Reviews, Vol. 68, No. 5, pp. 257-269.

O'Flynn, G., Coffey, A., Fitzgerald, G. F., \& Ross, R. P. (2006). The newly isolated lytic bacteriophages st104a and st104b are highly virulent against Salmonella enterica. Journal of Applied Microbiology, Vol. 101, No. 1, pp. 251-259. 
OzFoodNet Working Group (2009). Monitoring the incidence and causes of diseases potentially transmitted by food in Australia: annual report of the OzFoodNet Network, 2008. Communicable diseases intelligence, Vol. 33, No. 4, pp. 389-413.

Pao, S., Rolph, S. P., Westbrook, E. W., \& Shen, H. (2004). Use of Bacteriophages to Control Salmonella in Experimentally Contaminated Sprout Seeds. Journal of Food Science, Vol. 69, No. 5, pp. M127-M130.

Payne, R. J., Phil, D., \& Jansen, V. A. (2000). Phage therapy: the peculiar kinetics of selfreplicating pharmaceuticals. Clinical pharmacology and therapeutics, Vol. 68, No. 3, pp. 225-230.

Payne, R. J. H. \& Jansen, V. A. A. (2001). Understanding Bacteriophage Therapy as a Density-dependent Kinetic Process. Journal of Theoretical Biology, Vol. 208, pp. 37-48.

Petrov, V. M., Ratnayaka, S., Nolan, J. M., Miller, E. S., \& Karam, J. D. (2010). Genomes of the T4-related bacteriophages as windows on microbial genome evolution. Virology Journal, Vol. 7, pp. 292-.

Petty, N. K., Evans, T. J., Fineran, P. C., \& Salmond, G. P. C. (2007). Biotechnological exploitation of bacteriophage research. Trends in Biotechnology, Vol. 25, No. 1, pp. 715.

Rabinovitch, A., Aviram, I., \& Zaritsky, A. (2003). Bacterial debris-an ecological mechanism for coexistence of bacteria and their viruses. Journal of Theoretical Biology, Vol. 224, No. 3, pp. 377-383.

Rabsch, W., Tschape, H., \& Baumler, A. J. (2001). Non-typhoidal salmonellosis: emerging problems. Microbes and infection, Vol. 3, No. 3, pp. 237-247.

Raetz, C. R. \& Whitfield, C. (2002). Lipopolysaccharide endotoxins. Annual Review of Biochemistry, Vol. 71, pp. 635-700.

Ricci, V. \& Piddock, L. J. (2010). Exploiting the role of TolC in pathogenicity: identification of a bacteriophage for eradication of Salmonella serovars from poultry. Applied and Environmental Microbiology, Vol. 76, No. 5, pp. 1704-1706.

Robinson, D. A. (1981). Infective dose of Campylobacter jejuni in milk. British Medical Journal, Vol. 282, No. 6276, pp. 1584-.

Rohwer, F. (2003). Global phage diversity. Cell, Vol. 113, No. 2, pp. 141-.

Rosenquist, H., Sommer, H. M., Nielsen, N. L., \& Christensen, B. B. (2006). The effect of slaughter operations on the contamination of chicken carcasses with thermotolerant Campylobacter. International Journal of Food Microbiology, Vol. 108, No. 2, pp. 226-232.

Rosenquist, H., Nielsen, N. L., Sommer, H. M., Nørrung, B., \& Christensen, B. B. (2003). Quantitative risk assessment of human campylobacteriosis associated with thermophilic Campylobacter species in chickens. International Journal of Food Microbiology, Vol. 83, No. 1, pp. 87-103.

Sails, a. D., Wareing, D. R., Bolton, F. J., Fox, a. J., \& Curry, a. (1998). Characterisation of 16 Campylobacter jejuni and C. coli typing bacteriophages. Journal of medical microbiology, Vol. 47, No. 2, pp. 123-128.

Santos, S. B., Fernandes, E., Carvalho, C. M., Sillankorva, S., Krylov, V. N., Pleteneva, E. A., Shaburova, O. V., Nicolau, A., Ferreira, E. C., \& Azeredo, J. (2010). Selection and characterization of a multivalent Salmonella phage and its production in a nonpathogenic Escherichia coli strain. Applied and Environmental Microbiology, Vol. 76, No. 21, pp. 7338-7342. 
Santos, S. B., Kropinski, A. M., Ceyssens, P. J., Ackermann, H. W., Villegas, A., Lavigne, R., Krylov, V. N., Carvalho, C. M., Ferreira, E. C., \& Azeredo, J. (2011). Genomic and Proteomic Characterization of the Broad-Host-Range Salmonella Phage PVP-SE1: Creation of a New Phage Genus. Journal of Virology, Vol. 85, No. 21, pp. 1126511273.

Sapkota, A. R., Lefferts, L. Y., McKenzie, S., \& Walker, P. (2007). What do we feed to foodproduction animals? A review of animal feed ingredients and their potential impacts on human health. Environmental Health Perspectives, Vol. 115, No. 5, pp. 663-670.

Scott, A. E., Timms, A. R., Connerton, P. L., El-Shibiny, A., \& Connerton, I. F. (2007a). Bacteriophage influence Campylobacter jejuni types populating broiler chickens. Environmental microbiology, Vol. 9, No. 9, pp. 2341-2353.

Scott, A. E., Timms, A. R., Connerton, P. L., \{Loc Carrillo\}, C., \{Adzfa Radzum\}, K., \& Connerton, I. F. (2007b). Genome dynamics of Campylobacter jejuni in response to bacteriophage predation. PLoS pathogens, Vol. 3, No. 8, pp. e119-.

Sharp, R. J., Ahmad, S. I., Munster, A., Dowsett, B., \& Atkinson, T. (1986). The isolation and characterization of bacteriophages infecting obligately thermophilic strains of Bacillus. Journal of General Microbiology, Vol. 132, No. 6, pp. 1709-1722.

Sillankorva, S., Pleteneva, E., Shaburova, O., Santos, S., Carvalho, C., Azeredo, J., \& Krylov, V. (2010). Salmonella Enteritidis bacteriophage candidates for phage therapy of poultry. Journal of Applied Microbiology, Vol. 108, No. 4, pp. 1175-1186.

Smith, D. L., Dushoff, J., \& Morris, J. G. (2005). Agricultural antibiotics and human health. PLoS Medicine, Vol. 2, No. 8, pp. e232-.

Smith, D. L., Harris, A. D., Johnson, J. a., Silbergeld, E. K., \& Morris, J. G. (2002). Animal antibiotic use has an early but important impact on the emergence of antibiotic resistance in human commensal bacteria. Proceedings of the National Academy of Sciences of the United States of America, Vol. 99, No. 9, pp. 6434-6439.

Smith, H. W., Huggins, M. B., \& Shaw, K. M. (1987a). Factors Influencing the Survival and Multiplication of Bacteriophages in Calves and in Their Environment. Journal of General Microbiology, Vol. 133, No. 5, pp. 1127-1135.

Smith, H. W., Huggins, M. B., \& Shaw, K. M. (1987b). The control of experimental Escherichia coli diarrhoea in calves by means of bacteriophages. Journal of General Microbiology, Vol. 133, No. 5, pp. 1111-1126.

Sulakvelidze, A., Alavidze, Z., \& Morris, J. G. (2001). Bacteriophage therapy. Antimicrobial Agents and Chemotherapy, Vol. 45, No. 3, pp. 649-659.

Swann, M. M. (1969). Joint Committee on the use of Antibiotics in Animal Husbandry and Veterinary Medicine,Her Majesty's Stationery Office, London, United Kingdom.

Tacconelli, E., De, A. G., Cataldo, M. A., Pozzi, E., \& Cauda, R. (2008). Does antibiotic exposure increase the risk of methicillin-resistant Staphylococcus aureus (MRSA) isolation? A systematic review and meta-analysis. Journal of Antimicrobial Chemotherapy, Vol. 61, No. 1, pp. 26-38.

Timms, A. R., Cambray-Young, J., Scott, A. E., Petty, N. K., Connerton, P. L., Clarke, L., Seeger, K., Quail, M., Cummings, N., Maskell, D. J., Thomson, N. R., \& Connerton, I. F. (2010). Evidence for a lineage of virulent bacteriophages that target Campylobacter. BMC genomics, Vol. 11, pp. 214-. 
Toro, H., Price, S. B., McKee, A. S., Hoerr, F. J., Krehling, J., Perdue, M., \& Bauermeister, L. (2005). Use of bacteriophages in combination with competitive exclusion to reduce Salmonella from infected chickens. Avian Diseases, Vol. 49, No. 1, pp. 118-124.

Tsuei, A. C., Carey-Smith, G. V., Hudson, J. A., Billington, C., \& Heinemann, J. A. (2007). Prevalence and numbers of coliphages and Campylobacter jejuni bacteriophages in New Zealand foods. International Journal of Food Microbiology, Vol. 116, No. 1, pp. 121-125.

Turki, Y., Ouzari, H., Mehri, I., Ammar, A. B., \& Hassen, A. (2011). Evaluation of a cocktail of three bacteriophages for the biocontrol of Salmonella of wastewater. Food Research International, No. doi:10.1016/j.foodres.2011.05.041.

Uzzau, S., Brown, D. J., Wallis, T., Rubino, S., Leori, G., Bernard, S., Casadesus, J., Platt, D. J., \& Olsen, J. E. (2000). Host adapted serotypes of Salmonella enterica. Epidemiology and infection, Vol. 125, No. 2, pp. 229-255.

van de Giessen, A. W., Bouwknegt, M., Dam-Deisz, W. D., van, P. W., Wannet, W. J., \& Visser, G. (2006). Surveillance of Salmonella spp. and Campylobacter spp. in poultry production flocks in The Netherlands. Epidemiology and infection, Vol. 134, No. 6, pp. 1266-1275.

Velge, P., Cloeckaert, A., \& Barrow, P. (2005). Emergence of Salmonella epidemics: the problems related to Salmonella enterica serotype Enteritidis and multiple antibiotic resistance in other major serotypes. Veterinary Research, Vol. 36, No. 3, pp. 267-288.

Viscardi, M., Perugini, A. G., Auriemma, C., Capuano, F., Morabito, S., Kim, K. P., Loessner, M. J., \& Iovane, G. (2008). Isolation and characterisation of two novel coliphages with high potential to control antibiotic-resistant pathogenic Escherichia coli (EHEC and EPEC). International Journal of Antimicrobial Agents, Vol. 31, No. 2, pp. 152-157.

Waddell, T. E., Franklin, K., Mazzocco, A., Kropinski, A. M., \& Johnson, R. P. (2009). Generalized transduction by lytic bacteriophages. Methods Mol.Biol., Vol. 501, pp. 293-303.

Wagenaar, J. A., \{Van Bergen\}, M. A., Mueller, M. A., Wassenaar, T. M., \& Carlton, R. M. (2005). Phage therapy reduces Campylobacter jejuni colonization in broilers. Veterinary Microbiology, Vol. 109, No. 3-4, pp. 275-283.

Waldor, M. K. \& Mekalanos, J. J. (1996). Lysogenic conversion by a filamentous phage encoding cholera toxin. Science, Vol. 272, No. 5270, pp. 1910-1914.

Wall, S. K., Zhang, J., Rostagno, M. H., \& Ebner, P. D. (2010). Phage therapy to reduce preprocessing Salmonella infections in market-weight swine. Applied and Environmental Microbiology, Vol. 76, No. 1, pp. 48-53.

Whichard, J. M., Sriranganathan, N., \& Pierson, F. W. (2003). Suppression of Salmonella growth by wild-type and large-plaque variants of bacteriophage Felix O1 in liquid culture and on chicken frankfurters. Journal of Food Protection, Vol. 66, No. 2, pp. 220-225.

Wierup, M. (2001). The Swedish experience of the 1986 year ban of antimicrobial growth promoters, with special reference to animal health, disease prevention, productivity, and usage of antimicrobials. Microbial Drug Resistance, Vol. 7, No. 2, pp. 183-190. 
World Health Organization (2002). The use of antimicrobials outside human medicine: information from the World Health Organization on the health consequences. Journal of Environmental Health, Vol. 64, No. 9, pp. 66, 62-. 


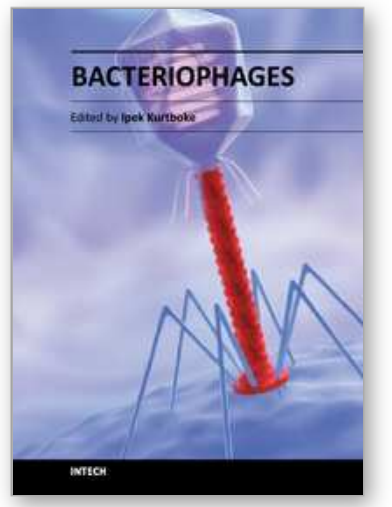

\author{
Bacteriophages \\ Edited by Dr. Ipek Kurtboke
}

ISBN 978-953-51-0272-4

Hard cover, 256 pages

Publisher InTech

Published online 14, March, 2012

Published in print edition March, 2012

Bacteriophages have received attention as biological control agents since their discovery and recently their value as tools has been further emphasized in many different fields of microbiology. Particularly, in drug design and development programs, phage and prophage genomics provide the field with new insights.

Bacteriophages reveals information on the organisms ranging from their biology to their applications in agriculture and medicine. Contributors address a variety of topics capturing information on advancing technologies in the field. The book starts with the biology and classification of bacteriophages with subsequent chapters addressing phage infections in industrial processes and their use as therapeutic or biocontrol agents. Microbiologists, biotechnologists, agricultural, biomedical and sanitary engineers will find Bacteriophages invaluable as a solid resource and reference book.

\title{
How to reference
}

In order to correctly reference this scholarly work, feel free to copy and paste the following:

Carla M. Carvalho, Sílvio B. Santos, Andrew M. Kropinski, Eugénio C. Ferreira and Joana Azeredo (2012). Phages as Therapeutic Tools to Control Major Foodborne Pathogens: Campylobacter and Salmonella, Bacteriophages, Dr. Ipek Kurtboke (Ed.), ISBN: 978-953-51-0272-4, InTech, Available from: http://www.intechopen.com/books/bacteriophages/phages-as-therapeutic-tools-to-control-the-majorfoodborne-pathogens-campylobacter-and-salmonella

\section{INTECH}

open science | open minds

\section{InTech Europe}

University Campus STeP Ri

Slavka Krautzeka 83/A

51000 Rijeka, Croatia

Phone: +385 (51) 770447

Fax: +385 (51) 686166

www.intechopen.com

\section{InTech China}

Unit 405, Office Block, Hotel Equatorial Shanghai No.65, Yan An Road (West), Shanghai, 200040, China 中国上海市延安西路65号上海国际贵都大饭店办公楼405单元 Phone: +86-21-62489820

Fax: $+86-21-62489821$ 
(C) 2012 The Author(s). Licensee IntechOpen. This is an open access article distributed under the terms of the Creative Commons Attribution 3.0 License, which permits unrestricted use, distribution, and reproduction in any medium, provided the original work is properly cited. 